\title{
Retrograde Regulation of Growth-Associated Gene Expression in Adult Rat Purkinje Cells by Myelin-Associated Neurite Growth Inhibitory Proteins
}

\author{
Marta Zagrebelsky, ${ }^{1}$ Annalisa Buffo, ${ }^{1}$ Arne Skerra, ${ }^{3}$ Martin E. Schwab, ${ }^{2}$ Piergiorgio Strata, ${ }^{1}$ and \\ Ferdinando Rossi ${ }^{1}$ \\ ${ }^{1}$ Department of Neuroscience, University of Turin, I-10125 Turin, Italy, ${ }^{2}$ Brain Research Institute, University of Zurich, \\ CH-8057 Zurich, Switzerland, and 3/nstitute of Biochemistry, Technische Hochschule, Darmstadt, D-64289 Germany
}

\begin{abstract}
Axon regeneration requires that injured neurons reinitiate longdistance growth and upregulate specific genes. To address the question of whether inhibitory environmental cues along the axon could exert a negative, tonic downregulation of growthassociated genes, we have examined adult rat Purkinje cells, which are endowed with poor regenerative capabilities. First we have compared their response to axotomy with that of neurons of the inferior olive, lateral reticular nucleus, and deep cerebellar nuclei, all of which vigorously regenerate into growthpermissive transplants. These injured neurons upregulate the transcription factors c-Jun and JunD, GAP-43, and NADPH diaphorase. In contrast, most axotomized Purkinje cells fail to express any of these markers, showing that the strength of this response parallels the regenerative potential of the examined neuron populations. However, strong upregulation of the same genes can be induced in Purkinje cells after colchicine injection into the uninjured adult cerebellum, indicating that their expres-
\end{abstract}

sion could be controlled by retrograde signals. To assess whether myelin-associated neurite growth inhibitory proteins contribute to this regulation, we applied the neutralizing antibodies IN-1 against one of the main inhibitory components of central myelin ( $\mathrm{NI}-250)$ either in vivo or in vitro to organotypic cerebellar cultures. Application of IN-1 antibodies induces the upregulation of c-Jun, JunD, and NADPH diaphorase in Purkinje cells, showing that their expression is suppressed constitutively by myelin-associated neurite growth inhibitors. Thus, the inhibitory activity of the IN-1 antigen on axon growth is not restricted to the control of growth cone motility but also involves a retrograde regulation of gene expression in adult central neurons.

Key words: axotomy; immediate early genes; growthassociated proteins; axon regeneration; intrinsic determinants; cerebellum; colchicine
Axon regeneration depends on the availability of favorable environmental conditions and on the capability of injured neurons to express a specific repertoire of growth-associated genes (Skene, 1989; Fawcett, 1992; Schwab and Bartholdi, 1996). The strength of the cell body reaction to axotomy differs among distinct neuron populations and correlates with their regenerative potential (Lieberman, 1971; Barron, 1989; Herdegen et al., 1993, 1997), indicating that each neuron class is endowed with peculiar regenerative properties. Nevertheless, within each neuron population the intensity and duration of this response depend on lesion conditions such as the distance from the soma (Doster et al., 1991; Hüll and Bähr, 1994a; Tetzlaff et al., 1994), the presence of uninjured collateral branches (Leah et al., 1993), and the sectioned axon branch, as with dorsal root ganglion neurons (Chong et al., 1991; Jenkins et al., 1993; Smith and Skene, 1997). In addition, the expression of growth-associated genes in injured neurons can be sustained by growth-permissive transplants (Hüll

\footnotetext{
Received May 27, 1998; revised July 6, 1998; accepted July 13, 1998.

This work was supported by grants from Ministero dell'Università della Ricerca Scientifica e Tecnologica, Consiglio Nazionale delle Ricerche, and European Community Biotechnology Programme (ERBBIO4-CT96-0774). We are grateful to Drs. Pico Caroni, Anne B. Oestreicher, and Rodrigo Bravo for the kind gift of different antibodies and mRNA probes. We thank Mrs. Luisella Milano for technical help and Miss Graziella Milano for secretarial assistance.

M.Z. and A.B. contributed equally to this paper.

Correspondence should be addressed to Dr. Ferdinando Rossi, Department of Neuroscience, University of Turin, Corso Raffaello 30, I-10125 Turin, Italy. Copyright (C) 1998 Society for Neuroscience $0270-6474 / 98 / 187912-18 \$ 05.00 / 0$
}

and Bähr, 1994b; Robinson, 1995; Vaudano et al., 1995; Chong et al., 1996; Broude et al., 1997) or the application of neurotrophins (Kobayashi et al., 1997). These observations indicate that the reaction to injury is not determined exclusively by intrinsic properties of the affected neurons, but it is influenced by environmental signals.

The nature of these signals and the mechanisms of this regulation remain to be elucidated. It has been proposed that the expression of growth-associated genes is suppressed in adult neurons by retrograde inhibitory cues (Skene, 1989, 1992). In the peripheral nervous system these signals are thought to derive from targets (Gold et al., 1993; Wu et al., 1993; Verzè et al., 1996; Smith and Skene, 1997). In the CNS, however, the reaction to injury can be weak or absent even after complete target loss, whereas the length of the axon stump can play a major role, suggesting that factors acting along the axon contribute to the regulation of growth-associated gene expression (Kalil and Skene, 1986; Doster et al., 1991; Skene, 1992). The myelinassociated neurite growth inhibitory proteins NI-35 and NI-250 (Caroni and Schwab, 1988a) are interesting candidate molecules for this function. Most in vitro assays of these proteins have focused on their inhibitory action on growth cone motility (Schwab et al., 1993; Bandtlow et al., 1996). However, their appearance during development parallels the downregulation of GAP-43 (Caroni and Schwab, 1989; Kapfhammer and Schwab, 1994a), and they also control the intracellular distribution of this protein in the adult (Kapfhammer and Schwab, 1994a,b). In 
addition, their neutralization allows for axonal regeneration and enhances plasticity in the adult brain (Schwab and Bartholdi, 1996; Thallmair et al., 1998; Z'Graggen et al., 1998).

To test the hypothesis that myelin-associated neurite growth inhibitors also could regulate the expression of regenerationassociated genes in central neurons, we have examined adult Purkinje cells, which show poor regenerative capabilities even in the presence of growth-permissive conditions (Rossi et al., 1995; Bravin et al., 1997; Dusart et al., 1997). We first compared Purkinje cell response to axotomy with that of other cerebellar or precerebellar neurons endowed with robust regenerative capabilities, and we found that the regenerative properties of these neuron populations parallel the strength of their reaction to injury. Then, by blocking axon flow, we asked whether injuryassociated gene expression in Purkinje cells is inhibited via retrograde signals. Finally, to determine whether this retrograde control is mediated by myelin-associated neurite growth inhibitors, we applied recombinant neutralizing IN-1 antibody Fab fragments to the cerebellum.

\section{MATERIALS AND METHODS}

Animals and surgical procedures. All of the experiments were performed on adult Wistar rats (Charles River, Calco, Italy) deeply anesthetized by means of intraperitoneal administration of a mixture of ketamine (100 $\mathrm{mg} / \mathrm{kg}$, Ketalar, Bayer, Leverkusen, Germany) and xylazine $(5 \mathrm{mg} / \mathrm{kg}$; Rompun, Bayer). The experimental plan was designed according to the Italian law for care and use of experimental animals (DL116/92) and approved by the Italian Ministry of Health.

We have studied the reaction to axotomy of four different cerebellar and precerebellar neuron populations (inferior olivary neurons, lateral reticular nucleus neurons, deep cerebellar nuclei neurons, and Purkinje cells) for which the axons were transected either in the cerebellar white matter (Dusart and Sotelo, 1994; Rossi et al., 1995) or in the cerebellar peduncles (Buffo et al., 1998). By the latter approach axons from the inferior olive and lateral reticular nucleus as well as the cerebellofugal projection from the deep nuclei are severed. By contrast, lesions of the cerebellar white matter affect Purkinje cell axons and the afferent projections to the cortex from the cerebellar and precerebellar nuclei. In this condition, however, olivocerebellar and mossy fiber pathways are affected only partially, and the axotomy is made far away from the cell body.

Cerebellar lesions were obtained according to a previously described method, which allows for the transection of the axial white matter of several cerebellar lobules (Dusart and Sotelo, 1994; Rossi et al., 1995). Briefly, the posterior surface of the cerebellum was exposed by drilling a hole in the occipital bone, and a microknife, made of a piece of a razor blade, was introduced into the cerebellar parenchyma and moved horizontally from the right to the left side of the vermis. Then the wound was sutured, and each animal was returned to its cage. A total of 14 animals who underwent this injury procedure and were killed at survival times ranging from $1 \mathrm{~d}$ to 1 month after the lesion (see Table1) were considered in this study. In addition, in another set of animals solid specimens of embryonic cerebellum $(n=8)$ or neocortex $(n=5)$ were transplanted into the lesion track immediately after the surgical transection (Table 1$)$. The preparation of the embryonic tissue and the grafting procedures were performed as previously described (Rossi et al., 1995; Bravin et al., 1997). Briefly, under general anesthesia, caesarean incisions were performed on pregnant rats, the embryos were collected in $0.12 \mathrm{M}$ phosphate buffer (PB) with $0.6 \%$ glucose, and the embryos were decapitated. The cerebellar primordium [from embryonic day 14 (E14) embryos] or neocortical tissue (from E17 embryos) was reduced in morsels and then pressure-injected into the lesion cavity, using a glass micropipette connected to a Hamilton syringe.

The unilateral transection of the cerebellar peduncles was performed on 29 rats (Table 1 ). In these animals the atlanto-occipital membrane was exposed and excised, and the cerebellar peduncles of one side was cut by inserting a microknife into the fourth ventricle underneath the cerebellum. These animals belong to an experimental set described in a previous study to which it can be referred for details about the surgical procedures and the evaluation of lesion extent (Buffo et al., 1998).

The Purkinje cell axonal transport was blocked in vivo by injecting a colchicine solution into the cerebellar parenchyma of uninjured rats. These animals were placed on a stereotaxic frame, the occipital bone was exposed, and a hole was drilled in the superior aspect to expose the cerebellar vermis. A total of $4 \mu \mathrm{g}$ of either colchicine $(n=17$, Table 1$)$ or $\beta$-lumicolchicine, as a control $(n=4$, Table 1$)$, diluted in $1 \mu$ l of saline solution was pressure-injected $1 \mathrm{~mm}$ deep within the cerebellar parenchyma around the midline at the level of lobule VI. As an additional control, $1 \mu$ l of saline solution $(n=6$, Table 1$)$ was injected according to the same method. The injection was performed by means of a glass micropipette connected to a PV800 Pneumatic Picopump (World Precision Instruments, New Haven, CT). The frequency and duration of pressure pulses were adjusted to inject $1 \mu$ l of the solution during $\sim 10$ min. Then, the pipette was left in situ for an additional $5 \mathrm{~min}$ to avoid an excessive leakage of the injected solution on the cerebellar surface.

In 19 intact rats (Table 1) a recombinant Fab fragment of the IN-1 antibody (produced in Escherichia coli), which neutralizes myelinassociated neurite growth inhibitory proteins (Bandtlow et al., 1996), was injected into the cerebellar parenchyma. In this case three $1 \mu$ l injections of Fab fragments in saline solution $(5 \mathrm{mg} / \mathrm{ml})$ were made $1 \mathrm{~mm}$ deep around the cerebellar midline along the anterior-posterior axis. The injections were made by means of a glass micropipette connected to a PV800 Pneumatic Picopump (World Precision Instruments). As a control an affinity-purified $\mathrm{F}\left(\mathrm{ab}^{\prime}\right)_{2}$ fragment mouse anti-human IgG (Jackson ImmunoResearch, West Grove, PA) was injected $(n=6$, Table 1$)$ by using the same procedure. In an additional set of animals $(n=7)$ the injection of Fab fragment solution was associated with the surgical transection of the cerebellar white matter (as above), which was performed during the same surgical session. Finally, five intact animals were examined as untreated controls.

Organotypic cerebellar cultures. Slice cultures were prepared according to the procedure described by Dusart et al. (1997). In our study postnatal day 10 Wistar rats (Charles River) were anesthetized deeply by means of

\section{Table 1. Number of animals examined for the in vivo experiments}

\begin{tabular}{|c|c|c|c|c|c|c|c|c|c|}
\hline \multirow[b]{2}{*}{$\begin{array}{l}\text { Survival } \\
\text { time (days) }\end{array}$} & \multicolumn{2}{|c|}{ Surgical lesions } & \multicolumn{7}{|c|}{ Intracerebellar injections } \\
\hline & $\begin{array}{l}\text { Peduncle } \\
\text { transection }\end{array}$ & $\begin{array}{l}\text { Cerebellar } \\
\text { lesion }\end{array}$ & $\begin{array}{l}\text { Cerebellar } \\
\text { lesion/graft }\end{array}$ & $\begin{array}{l}\text { Colchicine } \\
\text { injection }\end{array}$ & $\begin{array}{l}\beta \text {-Lumic. } \\
\text { injection }\end{array}$ & $\begin{array}{l}\text { Saline } \\
\text { injection }\end{array}$ & $\begin{array}{l}\text { IN-1 Fab } \\
\text { injection }\end{array}$ & $\begin{array}{l}\text { IN-1 Fab } \\
\text { injection/axotomy }\end{array}$ & $\begin{array}{l}\text { Control Fab } \\
\text { injection }\end{array}$ \\
\hline 1 & 6 & 2 & 1 & & & & & & \\
\hline 2 & 3 & & & 6 & 2 & 2 & 4 & 3 & 2 \\
\hline 3 & 3 & 2 & 4 & & & & & & \\
\hline 5 & 4 & & & & & 2 & 8 & 2 & 2 \\
\hline 7 & 4 & 3 & 4 & 3 & 2 & 2 & 7 & 2 & 2 \\
\hline 14 & 3 & 2 & 4 & 4 & & & & & \\
\hline 30 & 3 & 5 & & & & & & & \\
\hline 60 & 3 & & & 4 & & & & & \\
\hline
\end{tabular}

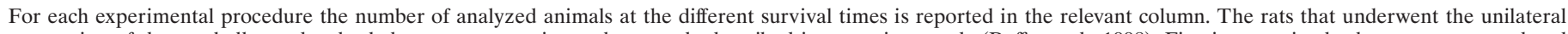

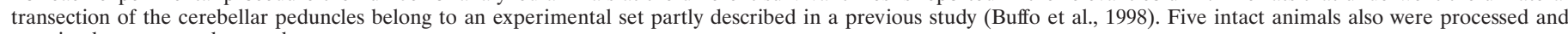
examined as untreated controls. 

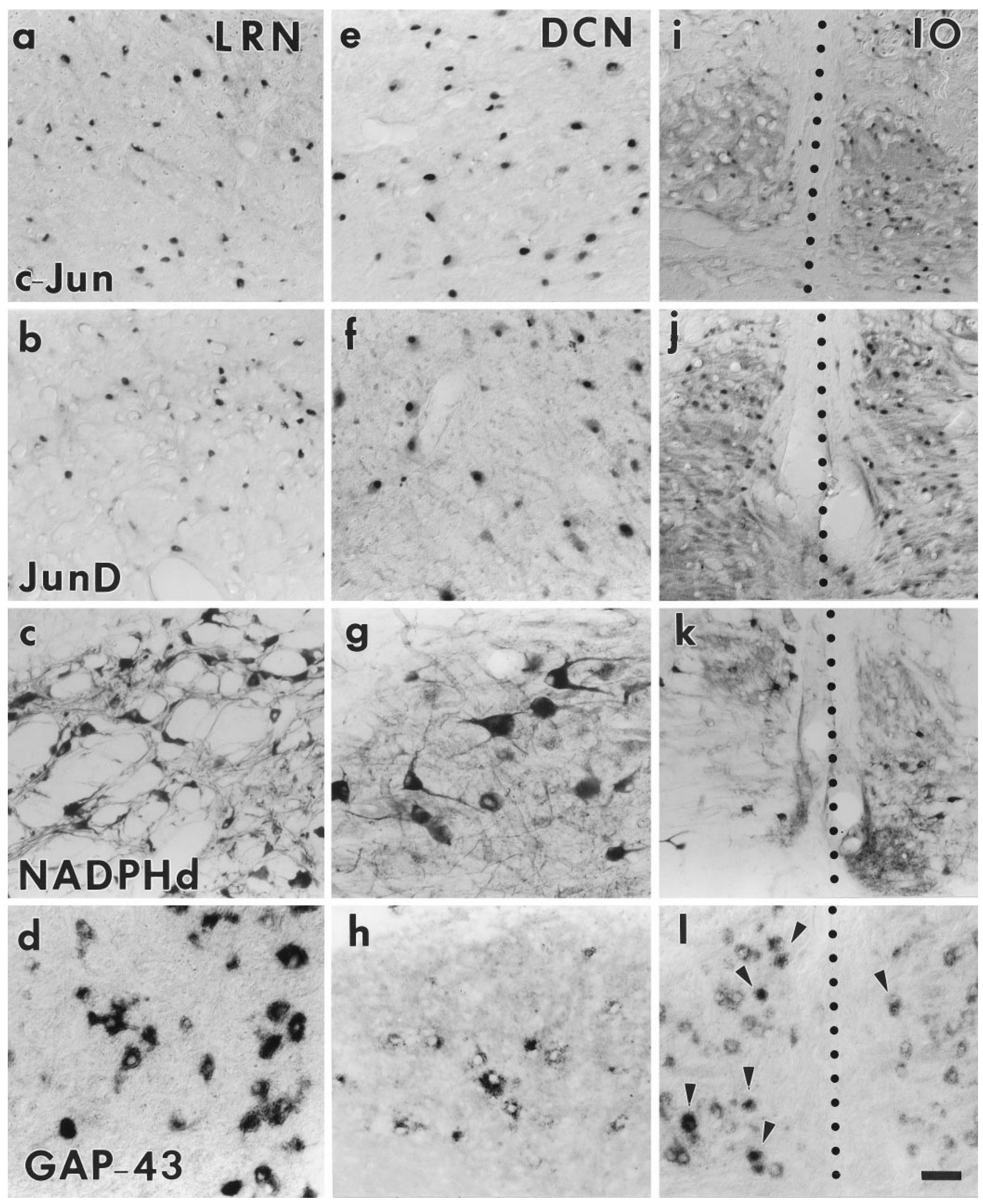

Figure 1. $a-l$, Response to axotomy of cerebellar and precerebellar neurons. The plate illustrates the expression of injury-associated markers in the lateral reticular nucleus $(L R N, a-d)$ after unilateral transections of the cerebellar peduncles and in the deep cerebellar nuclei $(D C N, e-h)$ and inferior olive (IO, $i-l$; dotted line indicates midline) after surgical injuries of the cerebellar white matter. The response to axotomy in these nuclei is consistent: numerous injured neurones become immunoreactive for c-Jun $(a, e, i)$, for JunD $(b, f, j)$, and for NADPH diaphorase histochemistry $(N A D P H d, c$, $g$, $k$ ) within all three nuclei. In addition, GAP-43 mRNA upregulation in these nuclei is revealed by $i n$ situ hybridization histochemistry $(G A P-43, d$, $h, l$ ). Arrowheads in $l$ point to inferior olivary neurons displaying a labeling intensity clearly above the basal level. Survival times, $7 \mathrm{~d}$. Scale bar, $50 \mu \mathrm{m}$. 

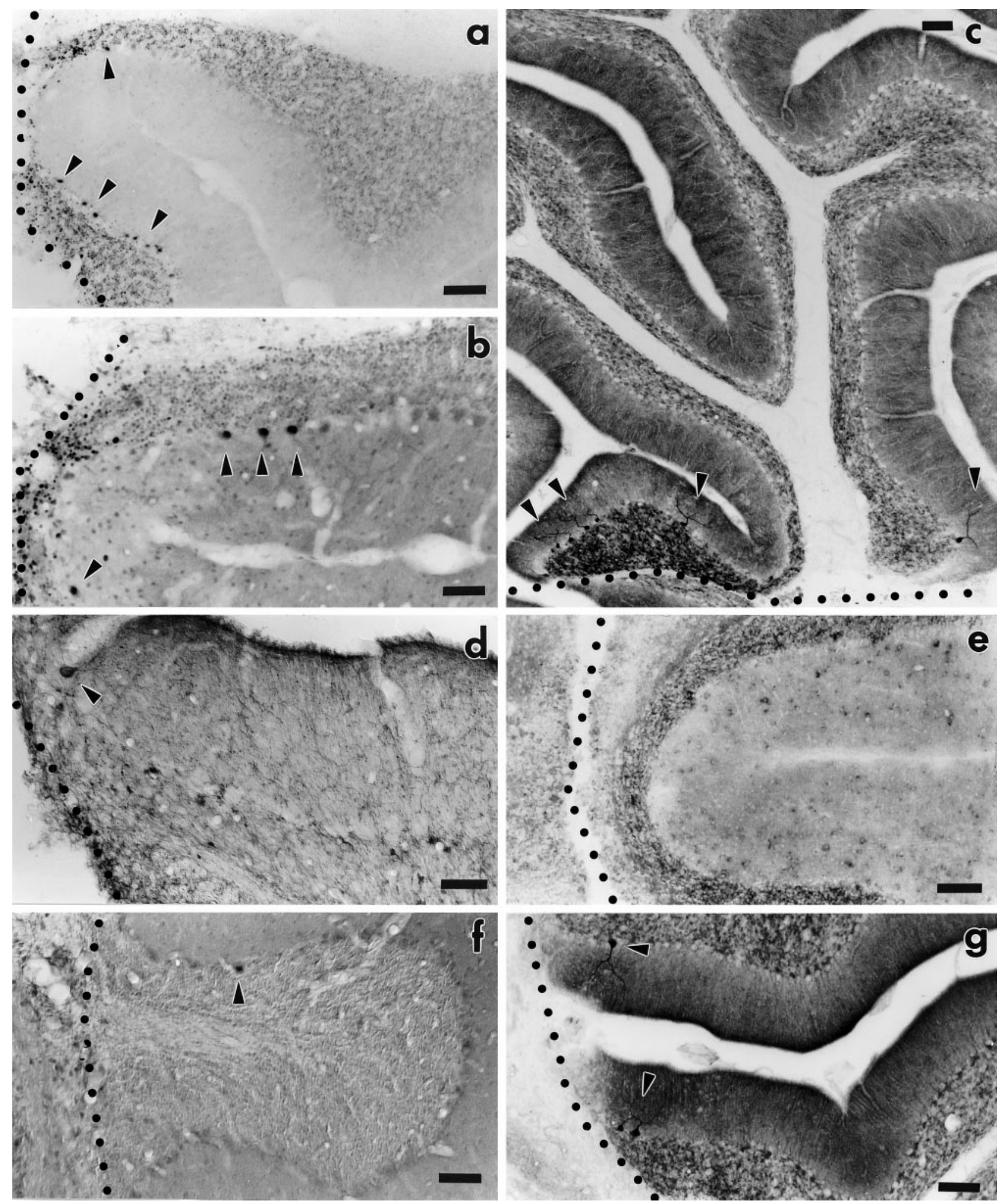

Figure 2. $a-g$, Response to axotomy of Purkinje cells. Micrographs $a-d$ show the expression of c-Jun $(a)$, JunD $(b)$, CAP-23 $(d)$, and NADPH diaphorase histochemistry $(c)$ in Purkinje cells after cerebellar lesions. Note that for all of these markers only a few labeled Purkinje cells (arrowheads in $a-d)$ are present and that they are always localized in the proximity of the injury track (dotted line in $a-e$ ), whereas more distant Purkinje cells for which the axons also have been transected are nonreactive. In situ hybridization histochemistry that is used to reveal GAP-43 mRNA is shown in $e$; the granular layer as well as interneurons in the molecular layer are stained, whereas no labeled Purkinje cells can be seen (dotted line points to lesion site). Similar results are obtained when embryonic cerebellar or neocortical grafts are placed into the lesion site ( $f$, $g$ display c-Jun immunolabeling and NADPH diaphorase histochemistry, respectively). Also, in these cases the few labeled neurons (arrowheads in $f, g$ ) are localized exclusively in the close vicinity of the lesion track, which now corresponds to the host-graft interface (marked by the dotted line in $f, g$ ). Survival times: $1 \mathrm{~d}$ in $a, b ; 7 \mathrm{~d}$ in $e-g ; 14 \mathrm{~d}$ in $d ; 30 \mathrm{~d}$ in $c$. Scale bars: $50 \mu \mathrm{m}$ in $b, d, f ; 100 \mu \mathrm{m}$ in $a, c, e, g$. 


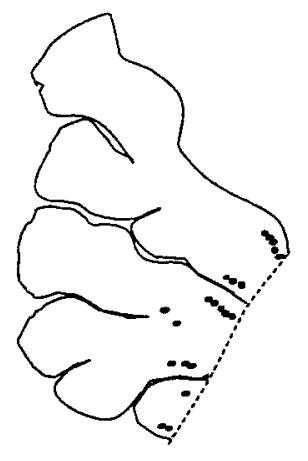

1d c-Jun

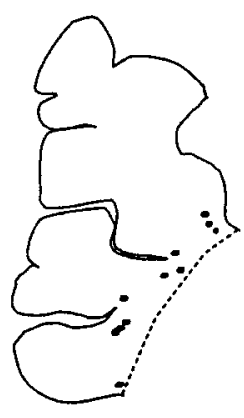

3d c-Jun

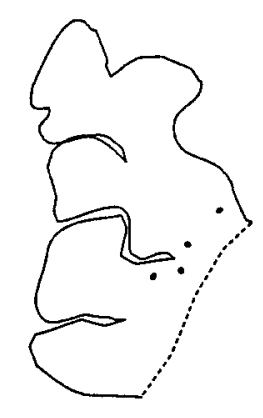

3d NADPHd

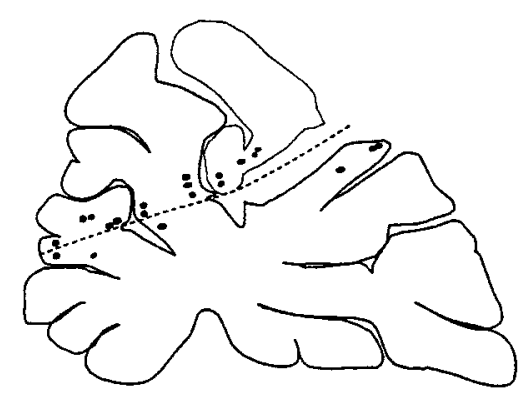

$7 d \mathrm{c}$-Jun

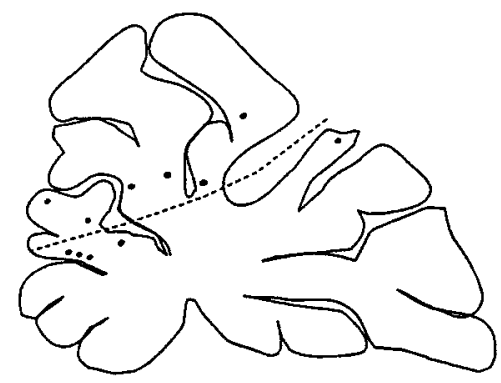

7d NADPHd

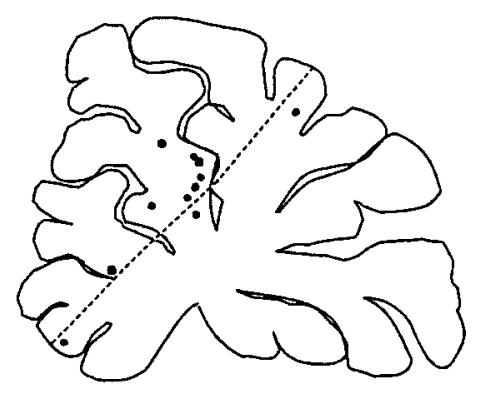

14d c-Jun

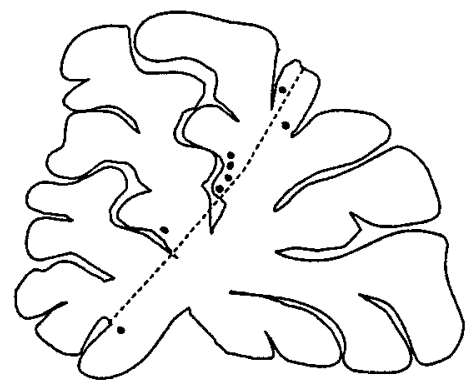

14d NADPHd

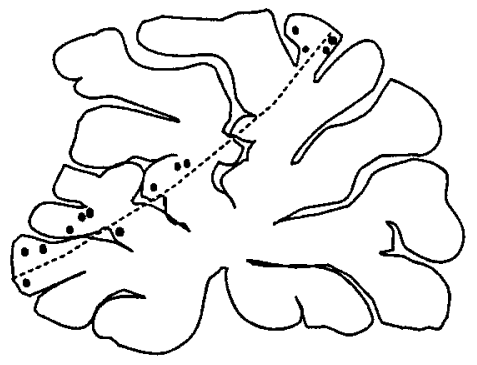

30d c-Jun

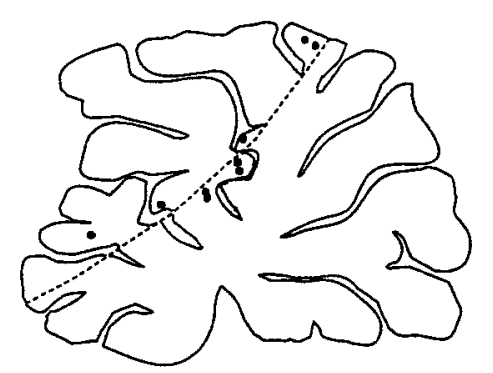

30d NADPHd
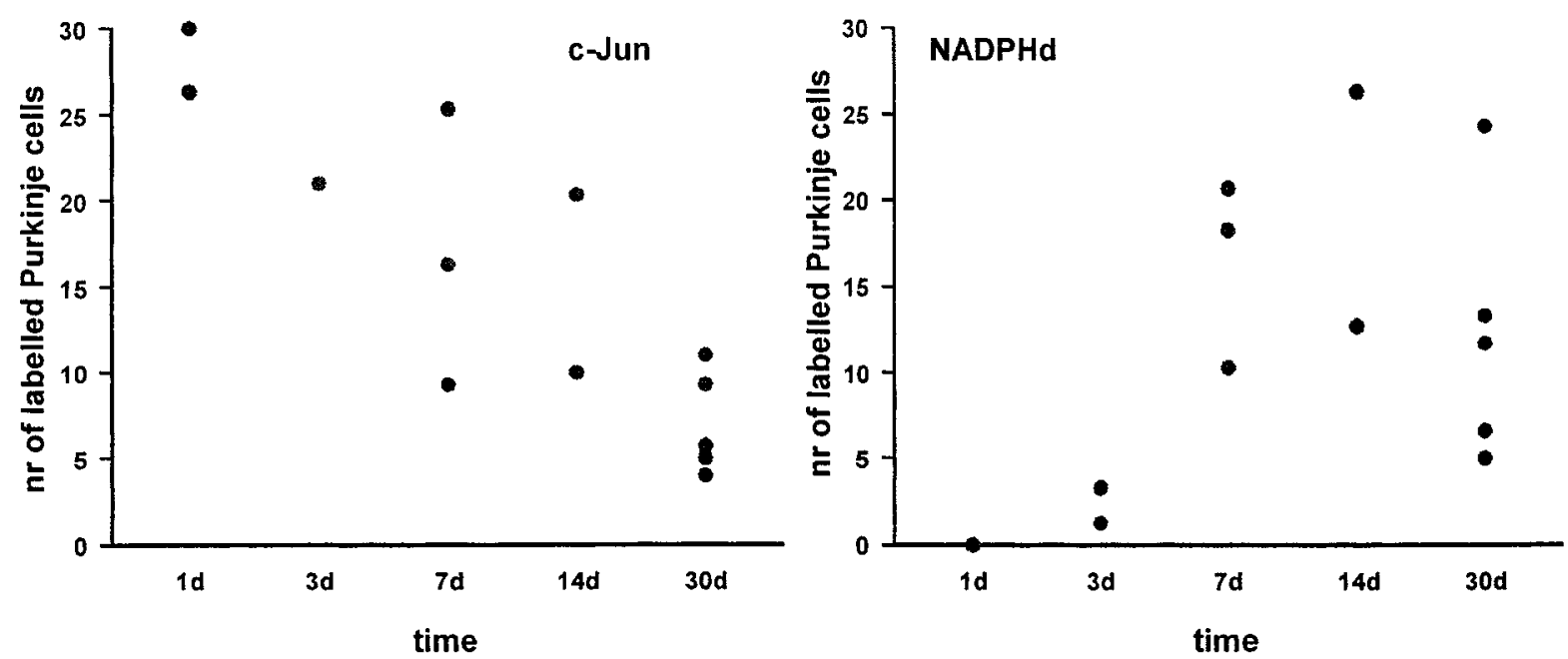
an intraperitoneal injection of a mixture of ketamine $(100 \mathrm{mg} / \mathrm{kg}$, Ketalar, Bayer) and xylazine $(5 \mathrm{mg} / \mathrm{kg}$, Rompun, Bayer) and transcardially perfused with $5 \mathrm{ml}$ of $0.12 \mathrm{M} \mathrm{PB}, \mathrm{pH} 7.2-7.4$, with $0.6 \%$ glucose to remove blood. Then the brains were dissected and placed into the same buffer, and the meninges were removed carefully. Cerebellar parasagittal slices, $400 \mu \mathrm{m}$ thick, were cut with a McIlwain tissue chopper and separated in $0.12 \mathrm{M}$ PB containing glucose. The slices then were cultured on the membrane of a $30 \mathrm{~mm}$ Millipore culture insert (Millicell, Millipore, Bedford, MA; pore size, $0.4 \mu \mathrm{m}$ ) in $10 \mathrm{~cm}$ culture dishes containing $3 \mathrm{ml}$ of a culture medium composed of $50 \%$ basal medium with Earle's salts (Life Technologies, Gaithersburg, MD), 2.5\% HBSS (Life Technologies), 25\% horse serum (Life Technologies), $22.5 \%$ water, $1 \mathrm{~mm}$ L-glutamine (Life Technologies), $200 \mathrm{U} / \mathrm{ml}$ penicillin/streptomycin (Life Technologies), and $5 \mathrm{mg} / \mathrm{ml}$ glucose. The cultures were kept at $37^{\circ} \mathrm{C}$ in a humidified atmosphere with $5 \% \mathrm{CO}_{2}$. After 1 week in culture the concentration of horse serum was lowered to $15 \%$.

All of the slices were kept for $7 \mathrm{~d}$ in culture before any manipulation. To cut Purkinje cell axons, we transected a set of slices $(n=27)$ by means of an ultramicrotomy glass knife under a dissecting microscope, according to a previously described approach (Dusart et al., 1997). Afterward, such injured slices were kept in culture for an additional period of time ranging from $48 \mathrm{hr}$ to $4 \mathrm{~d}$. To block axon flow, we placed some millicells containing cerebellar slices $(n=51)$ in a culture medium added with colchicine $(4 \mathrm{ng} / \mathrm{ml})$ for $15 \mathrm{~min}$. Then they were removed, carefully rinsed, and incubated with the normal culture medium for another 18-24 hr before being processed.

Another set of cerebellar slices, kept for $7 \mathrm{~d}$ in culture as previously described, were incubated with a culture medium supplied with hybridoma cells secreting either IN-1 antibodies $(n=116)$ or control antihorseradish peroxidase (HRP; $n=107$ ) antibodies (Caroni and Schwab, 1988b). Hybridoma cells were grown in Iscove's modified Dulbecco's medium supplemented with $6 \%$ fetal calf serum (Life Technologies), 2 mM L-glutamine (Life Technologies), $100 \mathrm{U} / \mathrm{ml}$ penicillin/streptomycin (Life Technologies), and $50 \mu \mathrm{M} \beta$-mercaptoethanol (Life Technologies) at $37^{\circ} \mathrm{C}$ in $5 \% \mathrm{CO}_{2}$ humidified atmosphere (see Caroni and Schwab, 1988b). The cells were counted, spun down, and resuspended in the medium used for slice culture at a concentration of $1 \times 10^{6}$ cells $/ \mathrm{ml}$ of medium. The slices were cultivated in this conditioned medium for a period from $24 \mathrm{hr}$ to $4 \mathrm{~d}$. In a separate experiment some cerebellar slices $(n=10)$ were incubated for $1-4 \mathrm{~d}$ with the recombinant Fab fragment of the IN-1 antibody (Bandtlow et al., 1996) diluted 1:10 in the slice culture medium. Finally, another set of cultures $(n=75)$, which remained in vitro for the same period of time, was processed and examined as untreated controls.

Histological procedures. At different postsurgery survival times under deep general anesthesia (as above), the rats were perfused transcardially with 11 of $4 \%$ paraformaldehyde in $0.12 \mathrm{M} \mathrm{PB}, \mathrm{pH}$ 7.2-7.4. The brains were dissected immediately, stored overnight in the same fixative at $4^{\circ} \mathrm{C}$, and finally transferred in a $30 \%$ sucrose in $0.12 \mathrm{M} \mathrm{PB}$ at $4^{\circ} \mathrm{C}$ until they sank. The cerebella were cut by means of a freezing microtome in several series of $30-\mu \mathrm{m}$-thick sagittal sections. Subsequently, one series of sections was processed for NADPH diaphorase histochemistry. These sections were incubated for $3-4 \mathrm{hr}$ in darkness at $37^{\circ} \mathrm{C}$ in a solution composed of $1 \mathrm{mg} / \mathrm{ml} \beta$-NADPH (Sigma, St. Louis, MO) and $0.2 \mathrm{mg} / \mathrm{ml}$ nitroblue tetrazolium (Sigma) in $0.12 \mathrm{M}$ PB with $0.25 \%$ Triton $\mathrm{X}-100$. All of the other series were incubated first in $\mathrm{H}_{2} \mathrm{O}_{2} 0.3 \%$ in PBS to neutralize endogenous peroxidase. They were incubated for $30 \mathrm{~min}$ at room temperature and then overnight at $4^{\circ} \mathrm{C}$ in the different primary antibodies: anti-calbindin D-28K (monoclonal, 1:5000; Swant, Bellinzona, Switzerland) to visualize Purkinje cells; anti-B-50/GAP-43 (rabbit immunoglobulins, 1:7000; gift of Dr. A. B. Oestreicher, Rudolf Magnus Institute, Utrecht, The Netherlands); anti-CAP-23 (polyclonal, 1:700; gift of Dr. P. Caroni, F. Miescher Institute, Basel, Switzerland); anti-c-Jun (polyclonal, 1:1000; Santa Cruz Biotechnology, Santa Cruz, CA); anti-junD (polyclonal, 1:8000; gift of Dr. R. Bravo, Myers Squibb Pharmaceutical Research Center, Princeton, NJ); and anti-c-Jun phosphorylated form (ser 63 and 73) (P-Jun, polyclonal, 1:10,000; New England Biolabs, Beverly, MA). All of the antibodies were diluted in PBS with $0.25 \%$ Triton X-100 added either with normal horse serum or normal goat serum, depending on the species of the second antibody. Immunohistochemical staining was performed according to the avidin-biotin-peroxidase method (Vectastain, ABC Elite kit, Vector Laboratories, Burlingame, CA) and was revealed by using $3,3^{\prime}$ diaminobenzidine $(0.03 \%$ in Tris-HCl) as a chromogen. For c-Jun, JunD, and P-Jun the reaction was intensified by adding $0.04 \%$ nickel ammonium sulfate to the diaminobenzidine solution. The reacted sections were mounted on chrome-alum gelatinized slides, air-dried, dehydrated, and coverslipped.

The organotypic cerebellar slides were fixed overnight at $4^{\circ} \mathrm{C}$ in $4 \%$ paraformaldehyde in $0.12 \mathrm{M} \mathrm{PB}, \mathrm{pH} 7.2-7.4$, and were detached carefully from the Millicell membrane before being processed for immunocytochemistry. All of the slices were double-stained by anti-c-Jun (polyclonal, 1:1000; Santa Cruz Biotechnology) and anti-calbindin antibodies (monoclonal, 1:3000; Swant). Both of the incubations in primary antibodies were performed at $4^{\circ} \mathrm{C}$ overnight. The c-Jun staining was revealed according to the avidin-biotin-peroxidase method (Vectastain, ABC Elite kit; Vector), using $3,3^{\prime}$ diaminobenzidine $(0.03 \%$ in Tris- $\mathrm{HCl})$ as a chromogen. Then the same slices were incubated in anti-calbindin, which was revealed via fluorescein isothiocyanate (FITC) immunofluorescence. Finally, the slices were mounted on chrome-alum gelatinized slides in PBS-glycerol and were coverslipped.

GAP-43 in situ hybridization. In situ hybridization histochemistry to reveal GAP-43 mRNA was performed on two intact and nine experimental rats killed $7 \mathrm{~d}$ after the different lesion/injection procedures described above (cerebellar lesion, $n=3$; peduncle transection, $n=2$; colchicine injection, $n=2$; IN-1 Fab application, $n=2)$. The rats were decapitated and brains were removed quickly by dissection. Tissue blocks were covered with Tissue-Tek embedding medium (Miles, Elkhart, IN) and rapidly frozen at $-40^{\circ} \mathrm{C}$ in 2-methyl-butane. The frozen tissue was stored at $-80^{\circ} \mathrm{C}$ for at least $24 \mathrm{hr}$ and up to several weeks. Sections $15 \mu \mathrm{m}$ thick were cut on a cryostat, collected on Superfrost slides, and air-dried at room temperature for $\sim 30 \mathrm{~min}$. Then the sections were fixed in $4 \%$ paraformaldehyde (freshly prepared in $0.1 \mathrm{M}$ PBS and stirred for $1 \mathrm{hr}$ at $70^{\circ} \mathrm{C}$ to dissolve) for $10 \mathrm{~min}$, washed in PBS, and permeabilized for 10 min in PBS with $0.1 \%$ Triton X-100. Next the sections were acetylated by a $10 \mathrm{~min}$ incubation in a solution made of $250 \mathrm{ml}$ of autoclaved distilled water with $3.5 \mathrm{ml}$ of triethanolamine (Sigma) and $625 \mu \mathrm{l}$ of acetic anhydride (Sigma) added dropwise. Prehybridization was performed at room temperature in a humid chamber in $500 \mu \mathrm{l}$ of the hybridization buffer $(50 \%$ formamide, $5 \times \mathrm{SSC}$, and $2 \%$ blocking reagent; Boehringer Mannheim, Mannheim, Germany). The hybridization mixture was prepared by adding $50 \mathrm{ng} / \mathrm{ml}$ of a full-length digoxigenated (DIG) riboprobe synthesized from GAP-43 containing plasmid (a kind gift of Dr P. Caroni, F. Miescher Institute, Basel, Switzerland) (Kapfhammer et al., 1997) that was heated first for $5 \mathrm{~min}$ at $85^{\circ} \mathrm{C}$ to denature the probe and then chilled on ice. Hybridization mixture was spread over the sections and coverslipped to maintain the concentration of formamide and salts. The hybridization was done overnight at $68^{\circ} \mathrm{C}$ in a hybridization mixture humidified chamber. Slides were washed by placing them vertically in a rack immersed in $5 \times$ SSC, and the coverslips were allowed to slide off. Stringency washing was performed in $0.2 \times \mathrm{SSC}$ at $68^{\circ} \mathrm{C}$ for $60 \mathrm{~min}$. For the immunological detection of DIG-labeled hybrids the slides were incubated for $1 \mathrm{hr}$ at room temperature in $1 \%$ blocking reagent made in maleic acid, incubated for $1 \mathrm{hr}$ in anti-DIG antibody (Boehringer Mannheim) diluted 1:5000 in 1\% blocking reagent, and finally washed twice for $30 \mathrm{~min}$ in maleic acid. To perform the color reaction, we incubated the slides with $2.4 \mathrm{mg}$ of levamisole (Sigma), $45 \mu \mathrm{l}$ of 4-nitroblue tetrazolium (Sigma), and $35 \mu \mathrm{l}$ of 5-bromo-4-chloro-3-indolyl-phosphate (Sigma) diluted in $10 \mathrm{ml}$ of a buffer made of (in $\mathrm{M}$ ) 0.1 Trizma base, $0.1 \mathrm{NaCl}$, and

\section{$\leftarrow$}

Figure 3. Spatial distribution and quantitative evaluation of c-Jun and NADPH diaphorase-positive Purkinje cells after axotomy. Neurolucida reconstructions of representative cerebellar sections labeled by c-Jun antibodies or NADPH diaphorase histochemistry at different survival times after lesion are shown. Note that reactive Purkinje cells (indicated by black dots) invariably are localized in the vicinity of the lesion track (dotted line). Only the portion of the section distal to the lesion is represented at 1 and 3 d survival times, because in these short-term cases the two halves of the sections separated during the histological procedures. The average number of labeled neurons per section is shown in the plots at the bottom of the plate. Each point represents the value obtained from a single animal. c-Jun-labeled neurons (left plot) are already present $1 \mathrm{~d}$ after injury, and their number gradually decreases thereafter. By contrast, NADPH diaphorase-reactive Purkinje cells (right plot) first appear at $3 \mathrm{~d}$ and progressively increase in number during the following weeks. Note, however, that in both instances only a very small number of Purkinje cells are present in each section. 

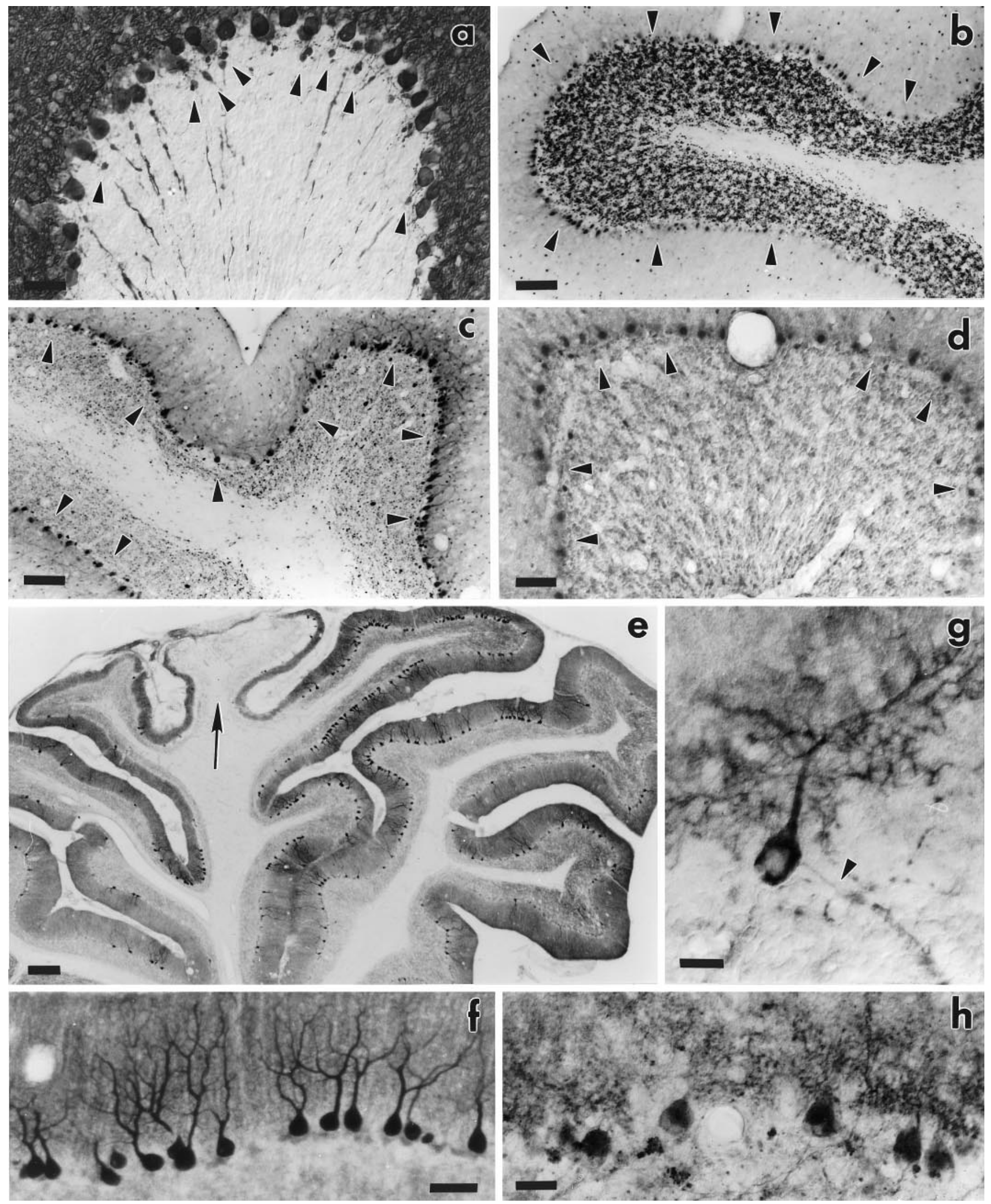

Figure 4. $a-h$, Response of Purkinje cells after intracerebellar injections of colchicine. Micrograph $a$ shows the morphological alterations of anti-calbindin-immunolabeled Purkinje cells, which mostly involve the formation of axonal torpedoes (arrowheads). Starting from the very first days after injection, numerous Purkinje cells (arrowheads in $b-d$ ) show a strong nuclear staining for c-Jun $(b)$, P-Jun $(d)$, and JunD $(c)$ immediate early genes. In addition, c-Jun expression is increased in granule cells $(b)$. A survey picture of a cerebellar section labeled for NADPH diaphorase histochemistry $14 \mathrm{~d}$ after colchicine injection is shown in $e$. The arrow points to the area of cortical atrophy around the injection site. Note, however, (Figure legend continues) 
$0.005 \mathrm{MgCl}, \mathrm{pH}$ 9.5. The color reaction was developed in the dark for 1-24 hr and stopped when the desired intensity was reached. Sections were mounted immediately in a glycerol solution made in PBS, and the coverslips were sealed with nail polish.

Quantitative analysis. Quantitative estimations of reactive Purkinje cells in the different in vivo experiments were made by estimating the neurons labeled by c-Jun antibodies or NADPH diaphorase histochemistry. For each treated animal three sections labeled for either marker were chosen according to the following criterion: only vermal sections close to the cerebellar midline, which contained the surgical injury track or the injection site (in the case of drug or antibody applications) were considered. Cell counts made on nine calbindin-immunolabeled vermal sections from three intact animals showed that each section contained on the average of $2061 \pm 116$ (SD) Purkinje cells. The selected sections from treated animals were reproduced by the Neurolucida software (Microbrightfield, Colchester, VT) connected with an E-800 Nikon microscope, and the position of every single labeled cell was marked carefully (see Figs. 3, 5, and 8 for several examples of such sections). Then the number of labeled cells present in the three reproduced sections was averaged to calculate the value for every single animal, which was represented individually in the plots of Figures 3, 5, and 8.

For in vitro experiments the number of c-Jun-immunolabeled Purkinje cells was estimated on nonaxotomized cerebellar slices treated for 1-4 d with hybridoma cells secreting IN-1 antibodies $(n=13)$, hybridoma cells secreting anti-HRP antibodies $(n=13)$, IN-1 Fab fragment $(n=10)$, or no treatment $(n=11)$. The analyzed cultures were selected randomly from parallel experimental runs, which were performed and processed simultaneously, to minimize differences caused by culture or histological processing. On each selected culture the total number of Purkinje cells, visualized by anti-calbindin immunofluorescence, was counted directly at the light microscope. The number of Purkinje cells displaying anti-c-Junlabeled nuclei was estimated simultaneously. The identification of such double-labeled Purkinje cells was checked carefully by frequently shifting from immunofluorescence to bright-field microscopy. The value calculated from each slice was represented individually in the plot of Figure 6 as the percentage of double-labeled Purkinje cells over the total number counted in the same culture. Statistical analysis was performed by Student's $t$ test.

\section{RESULTS}

\section{The response to axotomy of adult Purkinje cells and other cerebellar or precerebellar neurons parallels their different regenerative capabilities}

The different cerebellar axon populations are peculiar for their different regenerative properties. Olivocerebellar (Rossi et al., 1995; Bravin et al., 1997) and mossy fiber axons (Munz et al., 1985; Armengol et al., 1989) vigorously regenerate into growthpermissive grafts. Also, the axons from deep nuclear neurons can elongate into peripheral nerve implants (Dooley and Aguayo, 1982). In contrast, in the same experimental conditions adult Purkinje cell neurites are never able to grow (Dooley and Aguayo, 1982; Rossi et al., 1995; Bravin et al., 1997; Buffo et al., 1997; Dusart et al., 1997). Thus, we first asked whether such different regenerative capabilities also are paralleled by differences in the response to axotomy of these neuron populations. To this aim we examined the cellular changes occurring in injured Purkinje cells, deep cerebellar nuclei, lateral reticular nucleus, and inferior olive (see also Buffo et al., 1998) after unilateral transections of the cerebellar peduncles or lesions of the cerebellar white matter. In these injured neurons we investigated the expression of several well known injury-associated markers, including the immediate early genes c-Jun, JunD, and the phosphorylated form of c-Jun (P-Jun; Herdegen and Zimmermann,
1994; Herdegen et al., 1997; Yang et al., 1997), the growthassociated protein GAP-43 (Doster et al., 1991; Schaden et al., 1994; Tetzlaff et al., 1994), and the activity of NADPH diaphorase, which is known to be related to nitric oxide synthase (Herdegen et al., 1995). The base level of expression of these markers in intact animals was consistent with previous reports: no immunolabeling for immediate early genes (Herdegen et al., 1995) or NADPH diaphorase histochemistry (Saxon and Beitz, 1994, 1996) was observed in the examined neuron populations. Similarly, no GAP-43 mRNA could be detected in Purkinje cells, whereas in the deep cerebellar and lateral reticular nucleus only a few faintly labeled neurons were seen occasionally. By contrast, inferior olivary neurons throughout the whole extent of the nuclear complex displayed a clear constitutive expression (Kruger et al., 1993; Console-Bram et al., 1996). However, no GAP-43immunolabeled cell bodies were ever encountered in any of these nuclei.

A consistent response to axotomy was observed in the lateral reticular nucleus, deep cerebellar nuclei, and inferior olive (see also Buffo et al., 1998); after the unilateral transection of the cerebellar peduncles, numerous neurons in these nuclei became reactive for all of the examined markers (representative results from the lateral reticular nucleus are shown in Fig. 1a-d). Immediate early gene expression started from the very first days after injury (Fig. 1a,b), and GAP-43 and NADPH diaphorase activity increased during the second half of the first week (Fig. 1c,d). These changes were maintained substantially for the whole examined period, up to 1 month after lesion.

A similar response pattern and time course were observed after lesions in the cerebellar white matter. Numerous reactive neurons for all of the markers were present in the deep cerebellar nuclei (Fig. 1e-h). In addition, some neurons showing upregulation of immediate early genes, GAP-43, and NADPH diaphorase were found consistently in the medial regions of the inferior olive (Fig. $1 i-l)$, which are known to project to the posterior vermal cortex (Voogd et al., 1985) where the lesion was made. The limited number of reactive nerve cells found in the latter nucleus is consistent with the facts that only part of the olivocerebellar axons actually were touched by these lesions, the affected nerve cells were injured far from the cell body, and the collateral branches directed to the deep cerebellar nuclei likely were spared. Thus, these cerebellar and precerebellar neuron populations respond to axotomy by expressing the same repertoire of markers that also are upregulated in other brain regions (Doster et al., 1991; Herdegen and Zimmermann, 1994; Schaden et al., 1994; Tetztlaff et al., 1994). This indicates that the reaction to axotomy involves the expression of a stereotyped set of genes common to most nerve cells.

When Purkinje cells were examined in the same animals, completely different results were obtained: most of the Purkinje cells did not show any detectable c-Jun (Fig. 2a), P-Jun, and JunD expression (Fig. $2 b$ ). The only exception was a few neurons localized in the close proximity of the injury (Figs. 2a,b, 3). Quantitative estimation of c-Jun-positive Purkinje cells (plot in Fig. 3) showed that the average number of reactive neurons per section never exceeded a few dozen cells of 2061 ( \pm 116 SD)

that numerous labeled Purkinje cells are present over several cerebellar lobules. The morphology and labeling intensity of these reactive neurons are better appreciated in the higher magnification picture $f . g, h$ show anti-CAP-23-immunolabeled Purkinje cells $7 \mathrm{~d}$ after colchicine application. Purkinje cell somata, dendrites, and axons (arrowhead in $g$ ) are decorated by the immunoreaction product. Survival times: $2 \mathrm{~d}$ in $a-d ; 7 \mathrm{~d}$ in $g, h ; 14 \mathrm{~d}$ in $e, f$. Scale bars: $20 \mu \mathrm{m}$ in $g, h ; 50 \mu \mathrm{m}$ in $a, d, f ; 100 \mu \mathrm{m}$ in $b, c ; 200 \mu \mathrm{m}$ in $e$. 


\section{B-lumicolchicine}

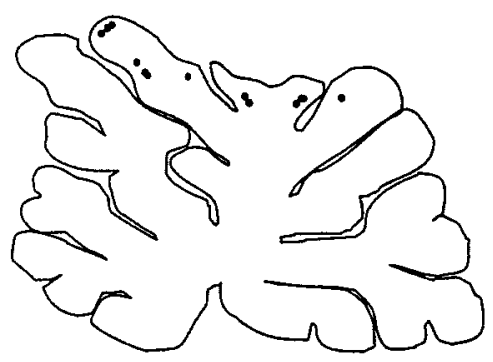

2d c-jun

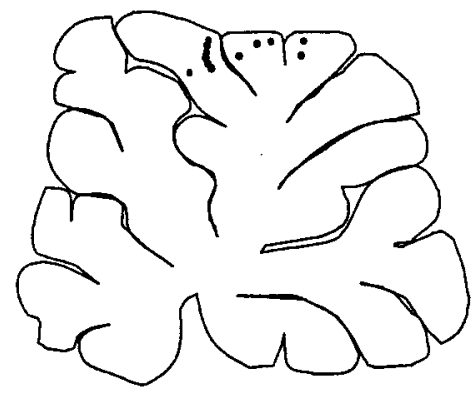

7d c-Jun

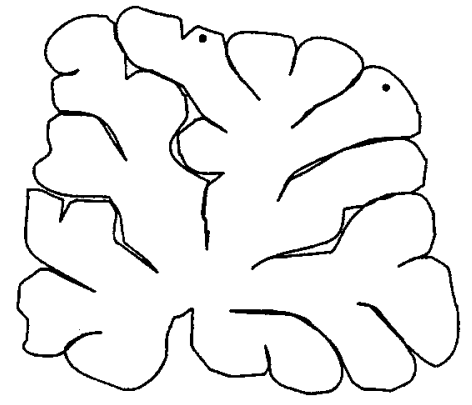

7d NADPHd

\section{colchicine}

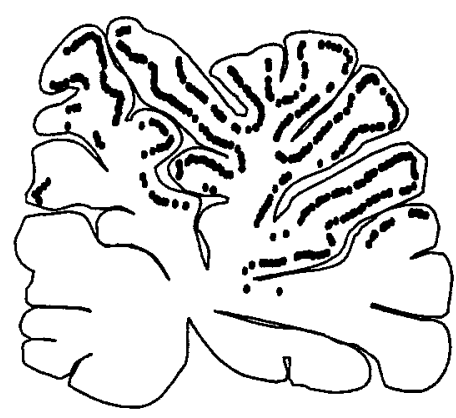

2d c-jun

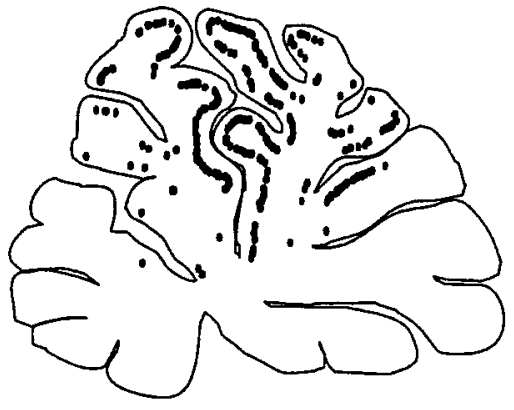

7d c-Jun

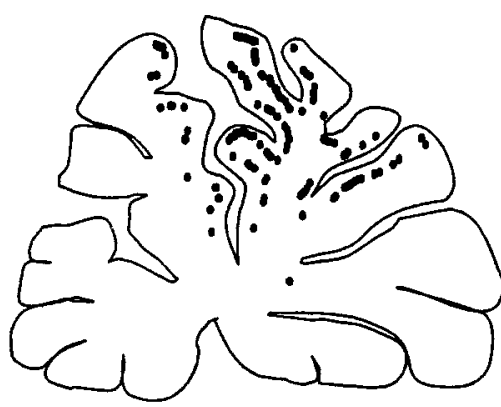

7d NADPHd

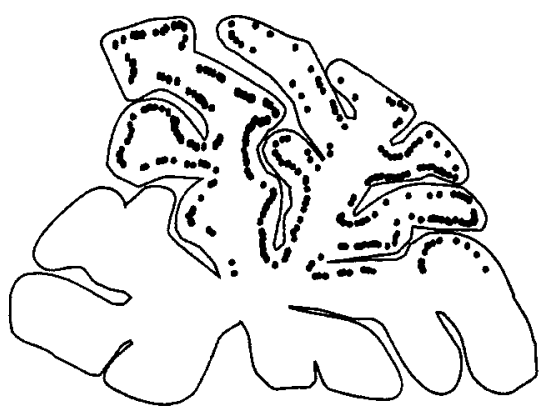

14d c-Jun

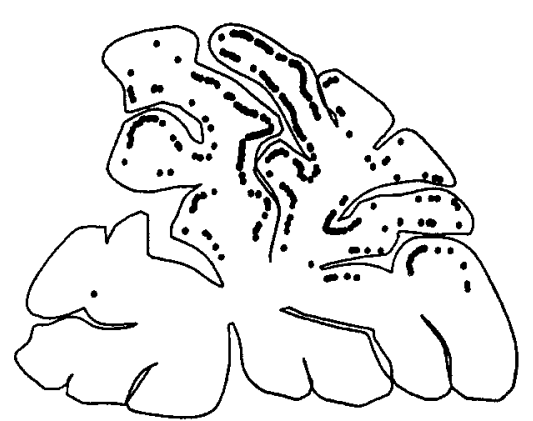

14d NADPHd

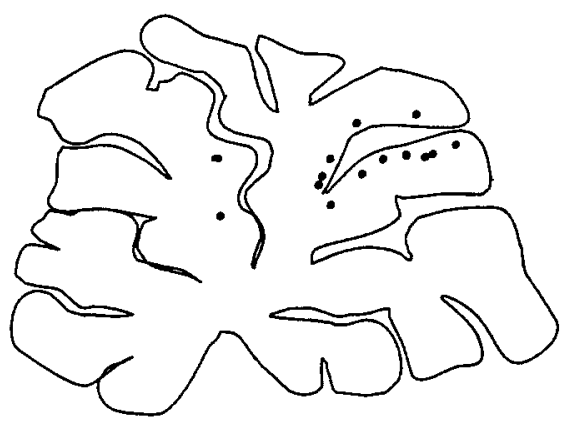

60d c-Jun

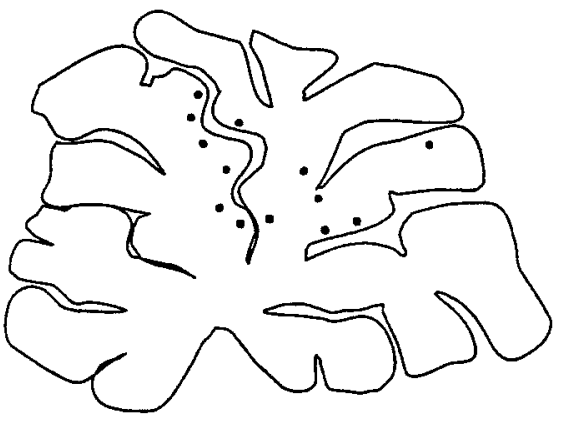

60d NADPHd
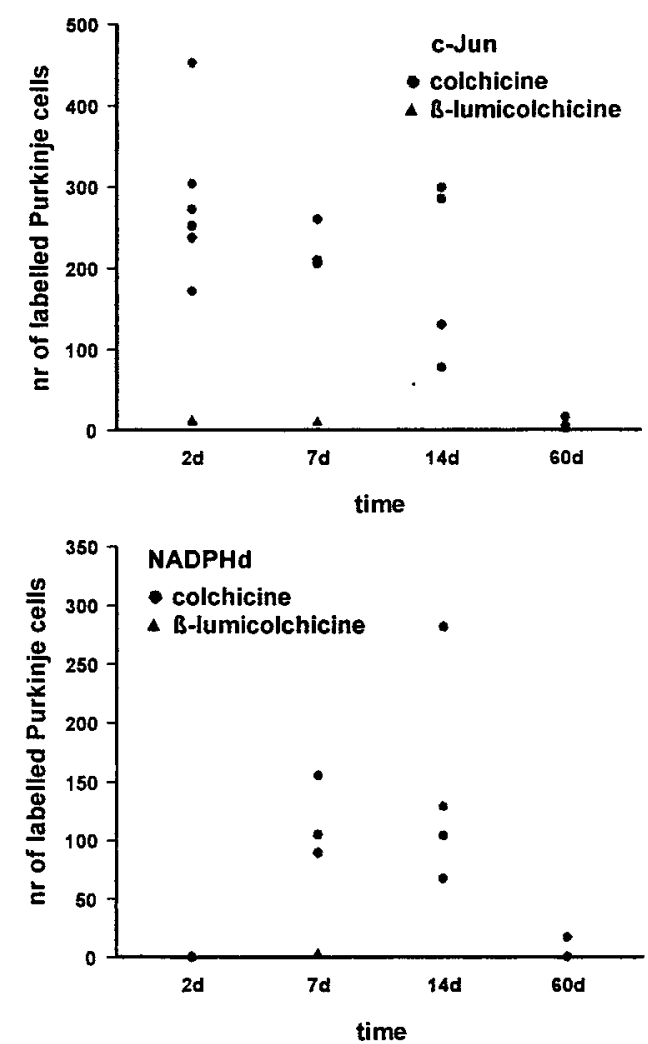

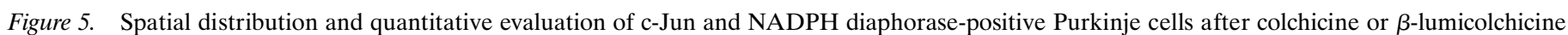

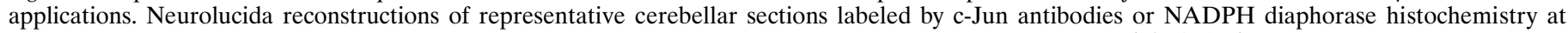

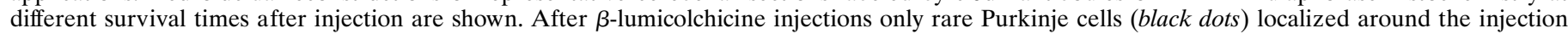

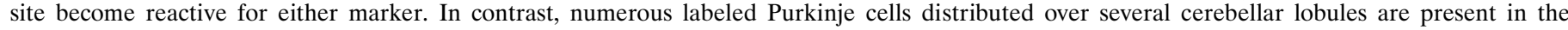

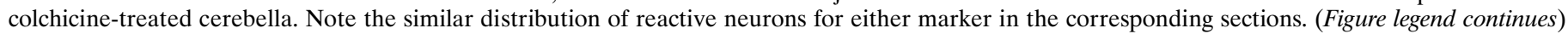


Purkinje cells that were estimated on similar sections from intact cerebella, and the number tended to decrease over time. A similar result was obtained by NADPH diaphorase histochemistry (see Fig. $2 c$ ): reactive Purkinje cells were restricted to the immediate vicinity of the lesion and first appeared $3 \mathrm{~d}$ after lesion. Their number increased during the following days, but they never exceeded a few dozen labeled neurons per section (plot in Fig. 3) (see also Chen and Aston-Jones, 1994; Saxon and Beitz, 1994, 1996). Consistent with previous results in the mouse (Buffo et al., 1997), we never observed GAP-43-immunoreactive Purkinje cell bodies or axons along the axial white matter of the transected folia, nor could we detect any GAP-43 mRNA expression in these axotomized neurons (see Fig. 2e). However, a few Purkinje cells in the vicinity of the lesion became immunoreactive for CAP-23 (see Fig. 2d), a protein that shares some functional homology with GAP-43 (Caroni, 1997). Thus, despite the large transections, which are known to induce the axotomy of virtually all Purkinje cells in the affected lobuli (Dusart and Sotelo, 1994; Rossi et al., 1995), only a few of these neurons, located close to the injury, reacted by expressing the cellular markers that are widely expressed by the other cerebellar or precerebellar neurons. Hence, the very poor regenerative behavior of Purkinje cells is paralleled by an inability to upregulate growth-associated genes in response to injury.

The expression of growth-associated genes can be enhanced in different neuron populations by the presence of growth-permissive/promoting tissues, such as peripheral nerve implants or embryonic grafts (Hüll and Bähr, 1994b; Robinson, 1995; Vaudano et al., 1995; Chong et al., 1996; Broude et al., 1997). Hence, we asked whether the expression of axotomy-associated genes in Purkinje cells could be enhanced by embryonic neural transplants. The grafts of E14 cerebellum or E17 neocortex placed into the injury track filled the lesion cavity being directly apposed to the transected folia. However, despite the proximity of the embryonic tissue, the pattern of marker expression in the injured Purkinje cells did not change (see Fig. $2 f-g$ ); only sparse neurons were reactive, and they were always located close to the injury site, now represented by the host-graft interface. This inability of the grafted tissues to induce or enhance the expression of growthassociated genes in Purkinje cells is consistent with the well established notion that such transplants cannot induce adult Purkinje axon growth either in vivo (Rossi et al., 1995; Bravin et al., 1997; Buffo et al., 1997) or in vitro (Dusart et al., 1997). In conclusion, the results of these experiments show that Purkinje cells do not upregulate growth-associated genes in response to axon injury as the other cerebellar or precerebellar neurons do, and this cellular behavior parallels the poor regenerative capability displayed by this nerve cell population even when confronted with growth-permissive environmental conditions.

\section{The expression of axotomy-associated genes can be induced in Purkinje cells by blocking axonal flow}

The observation that at least a few Purkinje cells display a cell body response after axotomy indicates that they are not intrinsically unable to express the injury-associated genes. Rather, the consistent localization of such reactive neurons in the close proximity of the injury site suggests that the distance from the lesion, and possibly the length of the axon stump, is a crucial parameter to determine whether they will respond or not. To elucidate this point further, we examined c-Jun expression of Purkinje cells after axotomy in organotypic slice cultures in which the relation between the cell body reaction and the length of the axon stump can be assessed directly. These experiments, described below, clearly showed that the only reactive Purkinje cells were those undergoing a very proximal injury, which left a short axon stump (see Fig. $6 a, b$ ). Thus, the response of Purkinje cells to injury is conditioned by the length of the remaining axon segment, indicating that their expression of growth-associated genes is inhibited by retrogradely transported signals.

To test this hypothesis, we blocked axonal transport with colchicine. Colchicine injection into the intact cerebellum in vivo induced a strong expression of c-Jun (Fig. 4b), P-Jun (Fig. 4d), and JunD (Fig. 4c) in numerous Purkinje cells distributed throughout several lobules around the injection site (Fig. 5). Quantitative estimation of c-Jun expression showed that several hundreds of reactive Purkinje cells per section were present from the very first days after lesion (Fig. 5). This expression was maintained for several weeks, and values returned to control levels after 2 months. Colchicine application also induced a strong NADPH diaphorase reactivity (see Fig. 4e,f) and CAP-23 immunolabeling (see Fig. $4 g, h$ ) in the same cerebellar lobuli. In contrast, Purkinje cells did not show GAP-43 immunostaining or GAP-43 mRNA upregulation (data not shown). The appearance of CAP-23 expression and NADPH reactivity was delayed with respect to the immediate early genes but was well evident at 7 and $14 \mathrm{~d}$ (Fig. 5). At 2 months after injection, NADPH diaphorasereactive cells were absent from three of the four examined animals, although one of them still displayed sparse labeled cells. CAP-23-immunoreactive neurons (see Fig. 4g, $h$ ) were consistently present between 1 and 2 weeks after injury, although their number was always far fewer than that of neurons labeled for the other markers. As a control experiment we injected $\beta$-lumicolchicine, which did not induce any expression of the examined markers in Purkinje cells except for a few neurons located around the injection cannula track (Fig. 5). Similarly, upregulation of immediate early genes, NADPH diaphorase, and GAP-43 also was observed in the examined cerebellar and precerebellar nuclei after application of colchicine, but not of $\beta$-lumicolchicine (data not shown).

As previously reported (Pioro and Cuello, 1988), colchicine treatment induced structural abnormalities in Purkinje cell axons, mostly involving the appearance of torpedoes (see Fig. 4a). In addition, because of its well established neurotoxic effect (Goldschmidt and Steward, 1982) an area of cortical atrophy and neuronal degeneration was evident around the injection site (Fig. $4 e)$. However, this area was much smaller than the area in which marker expression was induced. Indeed, the distribution of reactive Purkinje cells in the treated cerebella was consistent with a diffusion of colchicine along the axial white matter of several

\footnotetext{
The average number of labeled neurons per section is reported in the plots on the bottom right corner of the plate. Each point represents the value obtained from a single animal. Several hundreds of c-Jun-labeled neurons (top plot) are already present $2 \mathrm{~d}$ after injection, and this number essentially is maintained during the first weeks after injection. A considerable number of NADPH diaphorase-reactive neurons (bottom plot) can be found from $7 \mathrm{~d}$ after the injection onward. However, their number is constantly lower than that of c-Jun-positive Purkinje cells. At $60 \mathrm{~d}$ after injection, the number of reactive neurons for either marker is again at control level. Note the very small number of labeled neurons counted in the $\beta$-lumicolchicine-treated cerebella (indicated by filled triangles in the plots).
} 

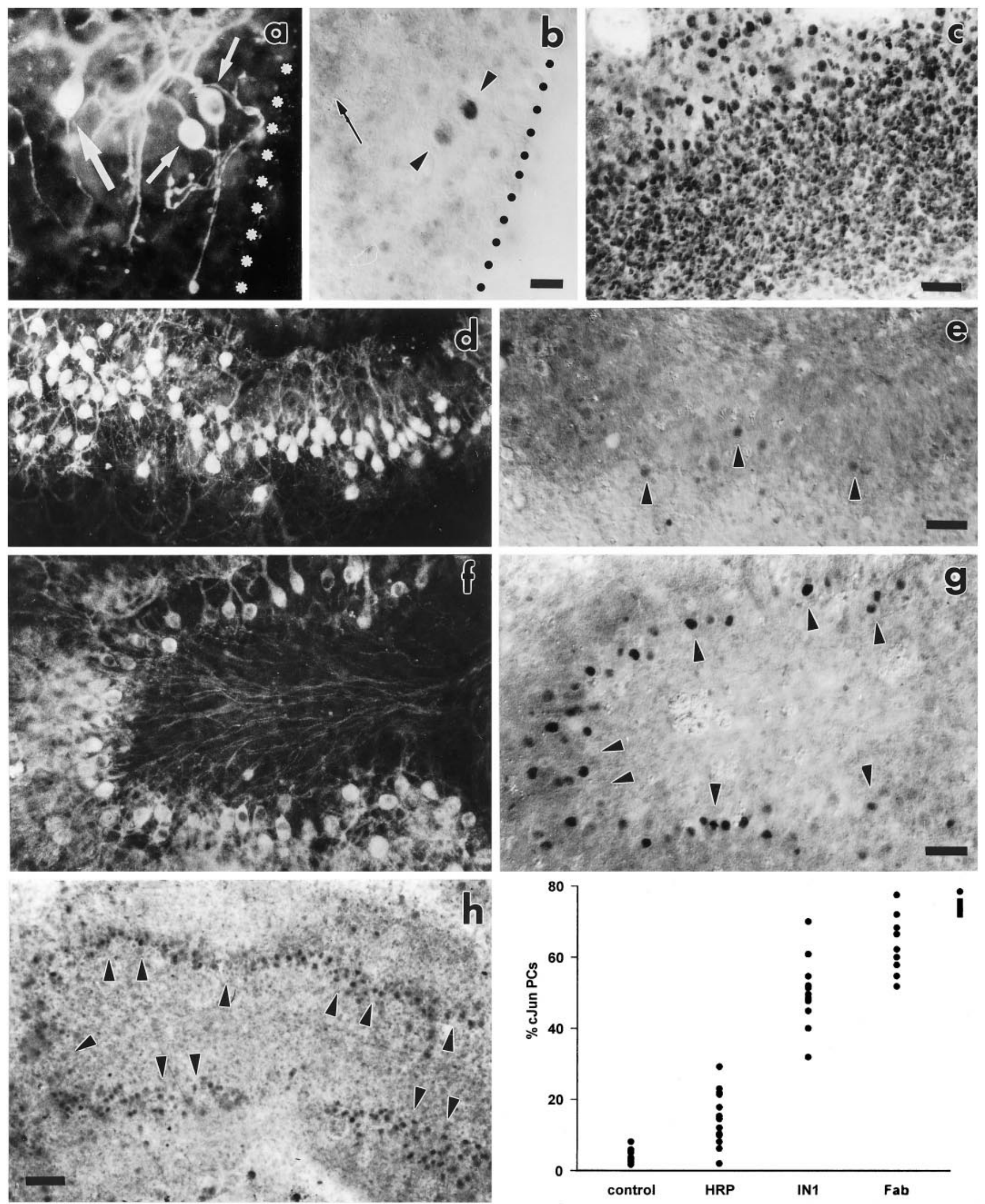

Figure 6. $a-i$, c-Jun expression in Purkinje cells in organotypic cerebellar cultures. c-Jun expression in axotomized Purkinje cells in vitro is shown in $a$ (anti-calbindin immunofluorescence) and $b$ (anti-c-Jun immunoperoxidase labeling). Two Purkinje cells (small arrows in $a$ ) localized close to the injury site (dotted line in $a, b)$ display c-Jun-immunoreactive nuclei (arrowheads in $b$ ); these cells are characterized by short axon stumps that measure a few hundred micrometers long. Another Purkinje cell (large arrow in a) displaying a longer axon stump does not express c-Jun (Figure legend continues) 
cerebellar lobuli around the injection site (Fig. 5). In addition, the comparison of the cerebella from animals killed at different survival times clearly showed that, although the effects of colchicine application on Purkinje cells (i.e., alterations of axonal morphology and gene expression) persisted for several weeks, in most of the affected cortical regions they were fully reversible and not associated with neuronal death (Fig. 5).

In conclusion, most of the markers that are expressed by cerebellar or precerebellar neurons after axon injury can be induced in Purkinje cells by colchicine treatment. The comparison with the application of $\beta$-lumicolchicine, which shares some of the biological actions of colchicine but is not able to depolymerize microtubules (Dasheff and Ramirez, 1985), indicates that this effect of colchicine may be attributed to the blockade of the axonal transport of retrograde signals that regulate gene expression in Purkinje cells. The Purkinje cell axon is myelinated starting at $40-50 \mu \mathrm{m}$ from the cell body, and the myelin sheath also covers all of the thin recurrent collateral ramifications (Palay and Chan-Palay, 1974). Thus, myelin-associated factors may be candidate molecules to regulate Purkinje cell gene expression.

\section{The application of IN-1 antibodies on organotypic cerebellar cultures induces $\mathrm{c}$-Jun expression in Purkinje cells}

To test the hypothesis that myelin-associated neurite growth inhibitors regulate gene expression in Purkinje cells, we first examined organotypic cerebellar cultures. The cerebellar slices were dissected from P10 animals and kept in vitro for $7 \mathrm{~d}$ before experimental manipulations were started. In intact cultures that remained $7-11 \mathrm{~d}$ in vitro, c-Jun was expressed only in $4 \%( \pm 1.9$ SD; Fig. $6 i$ ) of Purkinje cells, randomly scattered throughout the slice. When a cut was made across the slice, some c-Jun-labeled neurons consistently appeared along the edge of the lesion track. All of these reactive neurons underwent very proximal axotomies, which only spared a few hundred micrometer long axon stumps (Fig. 6a,b). Furthermore, a 15 min addition of colchicine to the culture medium of intact slices induced a strong immunoreactivity in Purkinje and granule cells all over the slice (Fig. 6c). Thus, in line with a previous report (Dusart et al., 1997), these in vitro experiments faithfully reproduced the results obtained on adult Purkinje cells in vivo.

We then examined the effect of neutralizing antibodies against myelin-associated neurite growth inhibitors. After $7 \mathrm{~d}$ in vitro, hybridoma cells secreting the IN-1 antibody, or an anti-HRP antibody as a control, were added to the culture medium in parallel sets of uninjured slices. The treated cultures contained the same number of Purkinje cells as the untreated ones (no treatment: $502 \pm 166 \mathrm{SD}, n=11$; IN-1 hybridoma: $537.1 \pm 229.1$ $\mathrm{SD}, n=13$; HRP hybridoma: $644 \pm 338.2 \mathrm{SD}, n=13$; IN-1 Fab fragment: $463.1 \pm 139 \mathrm{SD}, n=10)$. In addition, Purkinje cells did not show any visible morphological alteration that could be attributed to cell damage or degeneration (Fig. $6 f$ ).

The application of anti-HRP antibody led to a slight increase of c-Jun-labeled Purkinje cell nuclei $(14.7 \% \pm 7.7$ SD; Fig. $6 d, e, i)$, which was statistically different from untreated cultures $(4 \% \pm 1.9$ $\mathrm{SD}$; Student's $t$ test, $p<0.0001)$. Interestingly, in the IN-1-treated cultures numerous c-Jun-positive Purkinje cell nuclei were distributed rather uniformly over the whole slice (Fig. $6 f, g$ ). No clear granule cell labeling was observed (Fig. $6 g$ ). Quantitation of c-Jun-positive Purkinje cells showed that IN-1 treatment induced the expression of this gene in $49.8 \%$ ( \pm 9.2 SD, Fig. $6 i$ ) of Purkinje cells. This value was very different from that obtained from anti-HRP treated cultures (Student's $t$ test, $p<0.0001$ ), thus showing that the application of the IN-1 antibody was effective in inducing c-Jun expression in Purkinje cells. To validate this result further, we added the recombinant Fab fragment of the IN-1 antibody to the medium in another set of slices (Fig. 6h). The result of this experiment showed that $63 \%( \pm 8$ SD; Fig. $6 i)$ of Purkinje cells expressed c-Jun. This number was statistically different from that obtained from IN-1 hybridoma-treated cultures (Student's $t$ test, $p=0.001$ ). This difference may be attributed to the fact that the smaller-sized Fab fragments more easily penetrate into the slice than the hybridoma-secreted IgM. Thus, c-Jun expression is induced in Purkinje cells in vitro by the application of neutralizing antibodies against the myelinassociated neurite growth inhibitors, indicating that these proteins are involved in the regulation of growth-associated genes in Purkinje cells.

\section{Injection of the Fab fragment of the IN-1 antibody induces the expression of axotomy-associated genes in Purkinje cells in vivo}

To assess whether myelin-associated neurite growth inhibitors regulate Purkinje cell gene expression in vivo, we injected the Fab fragment of the IN-1 antibody, or a mouse anti-human IgG Fab fragment as a control, into the intact adult cerebellum. Injection of the control Fab fragment, like that of saline solution, induced the expression of the different markers in only a few Purkinje cells located around the cannula track (see Fig. 8). In contrast, the application of IN-1 Fab fragments induced a strong expression of several markers in large cerebellar areas (Figs. 7a-e, 8). Immediate early gene expression already was evident in numerous cells at $2 \mathrm{~d}$, the shortest survival time that was examined (Fig. 7a-d). As shown in Figures $7 a$ and 8, labeled Purkinje cells were distributed over large areas of the cerebellum around the injection site. Most interestingly, no labeling was observed in granule cells, except for a few neurons exclusively localized in the close proximity of the cannula track, for which the axons most likely had been injured during the penetration of the injection pipette (Fig. $7 a$ ). Similarly,

$\longleftarrow$

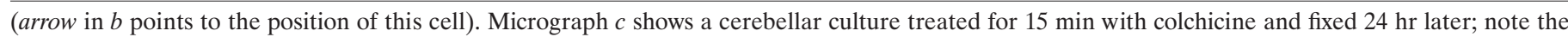

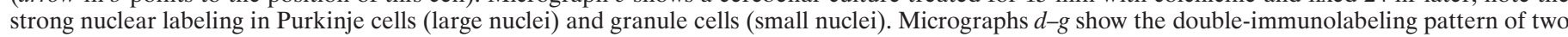

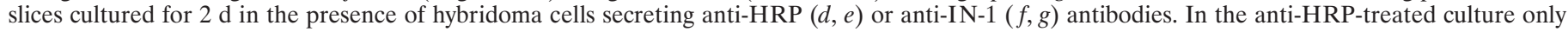

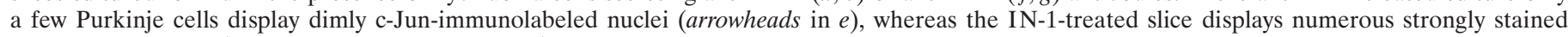

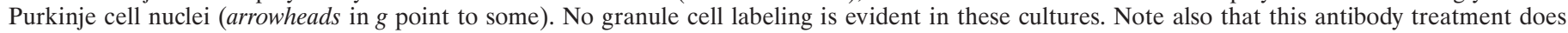

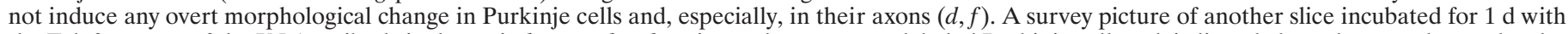

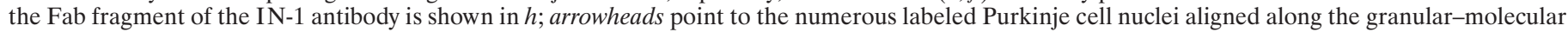

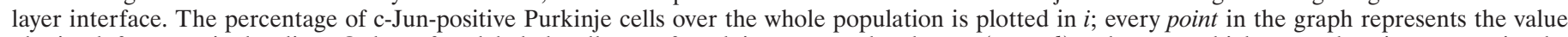

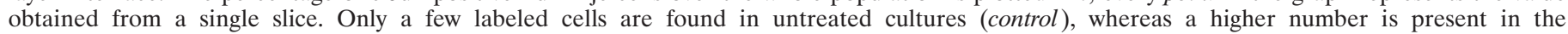

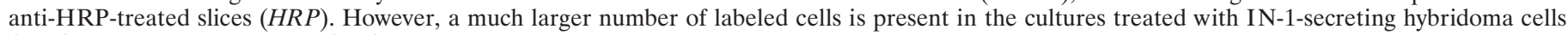
$(I N-1)$ or IN-1 Fab fragments $(F a b)$. Scale bars: $20 \mu \mathrm{m}$ in $b ; 50 \mu \mathrm{m}$ in $c, e, g ; 100 \mu \mathrm{m}$ in $h$. 

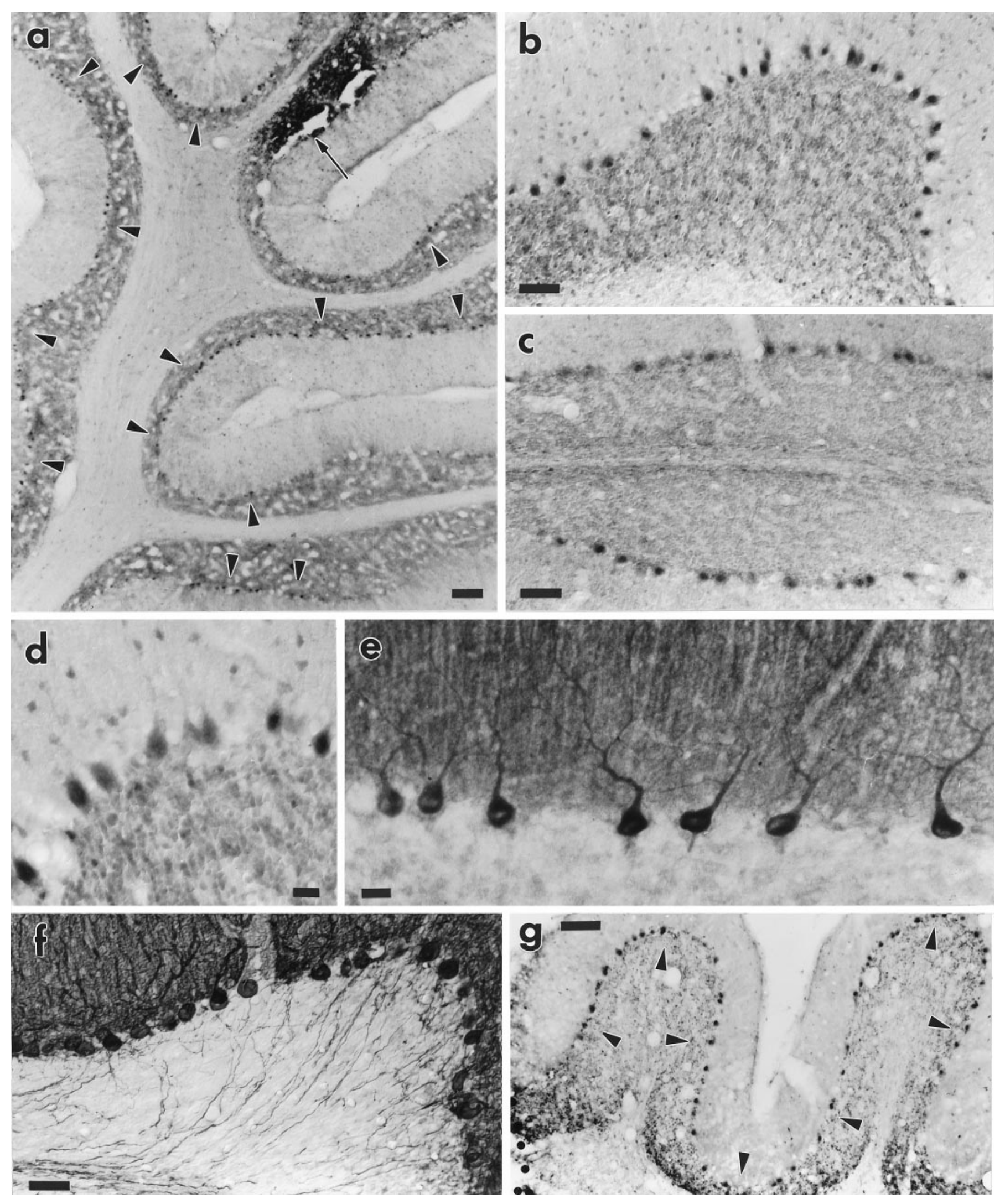

Figure 7. $a-g$, In vivo response of Purkinje cells to intracerebellar injections of the Fab fragment of the IN-1 antibody. The injection of the Fab fragment of the IN-1 antibody induces a strong expression of several markers in Purkinje cells. Immediate early genes are upregulated already at 48 hr after the injection in several cerebellar lobuli all around the injection site. $a, b, c-J u n$ expression is shown. Positive Purkinje cells are distributed over several cerebellar lobules (arrowheads in $a$ ). Note that granule cell labeling is restricted to a small area along the cannula track (marked by the arrow in $a$ ) where granule cell axons most likely have been injured by the injection pipette. Similarly, numerous Purkinje cell nuclei are stained by anti-P-Jun $(c)$ and anti-JunD $(d)$ antibodies. Micrograph $e$ shows NADPH diaphorase-reactive Purkinje cells $5 \mathrm{~d}$ after injection. Anti-calbindin (Figure legend continues) 
the expression in other cortical interneurons did not exceed basal levels.

At $5 \mathrm{~d}$ after the injection, numerous Purkinje cells still expressed the immediate early genes (see Fig. 8 for c-Jun distribution and quantification). In addition, at this survival time the Purkinje cells, distributed over the same areas as the other markers, became strongly reactive for NADPH diaphorase histochemistry (Figs. 7e, 8). The number of such reactive neurons was variable among the examined animals. A high number of positive Purkinje cells ( $\sim 100$ per section) were present in the two animals with the highest number of c-Jun-positive cells. In the other cases only a few tens of Purkinje cells were observed, but they were always more numerous than those in time-matched controls (Fig. 8). Finally, at $7 \mathrm{~d}$ the number of labeled Purkinje cells for all of the examined markers returned almost to control levels (Fig. 8), indicating that the single Fab injections exerted a transitory effect, which faded within 1 week after application. No labeling for GAP-43 or CAP-23 was observed in Purkinje cells during this period. It is worth mentioning also in these in vivo experiments that the analysis of anti-calbindin-immunolabeled cerebella at all survival times did not show signs of regressive or dystrophic changes in Purkinje cells or in their axons (see Fig. 7f).

Finally, to test whether the neutralization of myelin-associated neurite growth inhibitors also affected gene expression in axotomized Purkinje cells, the IN-1 Fab fragment was injected into the transected lobuli of injured cerebella. The results of these experiments were essentially similar to those from injections into intact cerebella: numerous Purkinje cells distributed over the whole transected folia and also far away from the lesion site (see Fig. $7 g$ ) were immunoreactive for the immediate early genes within $2 \mathrm{~d}$ after the lesion/injection procedure; NADPH diaphorase reactivity appeared a few days later. Again, these markers disappeared at $7 \mathrm{~d}$.

In conclusion, these results show that the expression of several axotomy-associated genes in Purkinje cells can be induced in vivo when the activity of $250 \mathrm{kDa}$ myelin-associated neurite growth inhibitor is neutralized by the Fab fragment of the specific blocking antibody IN-1. Thus, these molecules effectively regulate the expression of these genes in intact and injured Purkinje cells.

\section{DISCUSSION}

We have studied the expression and regulation of injuryassociated markers in adult Purkinje cells to assess whether their poor regenerative capabilities can be related to a weak cell body reaction to axotomy. Then we asked whether this lack of reactivity depends on intrinsic features of these neurons or is determined by environmental influences. We show that (1) different neuron populations respond to injury by expressing a common set of markers, including several immediate early genes, GAP-43, CAP-23, and NADPH diaphorase reactivity; (2) the strength of this response parallels the regenerative capabilities of the different neuron types, being most weak or absent in Purkinje cells; (3) however, Purkinje cells upregulate these genes when their axonal flow is blocked or when the axotomy occurs very close to the perikaryon, indicating that their expression is controlled by retrogradely transported signals; and (4) a similar upregulation is induced by applying IN-1 antibodies that neutralize myelinassociated neurite growth inhibitory proteins. Thus, the expression of injury or growth-associated genes in Purkinje cells is prevented constitutively by the latter proteins, and this inhibition likely accounts, at least in part, for the weak regenerative response of Purkinje cell bodies and the constant failure of these neurons to regenerate their axons (Rossi et al., 1995; Bravin et al., 1997; Buffo et al., 1997; Dusart et al., 1997).

\section{The cell body reaction and its relation to axon regeneration}

Axon regeneration requires that the injured neurons undergo specific metabolic changes (Lieberman, 1971; Barron, 1989), and several genes expressed during this response recently have been identified (Doster et al., 1991; Herdegen and Zimmermann, 1994; Schaden et al., 1994; Tetzlaff et al., 1994; Caroni, 1997; Herdegen et al., 1997). The cellular changes as well as the repertoire of molecules induced after axotomy are similar in most neuron populations. However, the intensity of this response differs among distinct nerve cell categories and also according to injury conditions, usually being correlated to the regenerative potential shown by the affected neurons when confronted with a growthpermissive milieu (Doster et al., 1991; Jenkins et al., 1993; Schaden et al., 1994; Tetzlaff et al., 1994). Observations made in this study for the cerebellar and precerebellar neurons confirm these concepts: the pattern of axotomy-induced gene expression in these neurons is similar to that shown by other neuron populations except for the lack of GAP-43 upregulation in Purkinje cells. However, the latter neurons do not express GAP-43 during development (Console-Bram et al., 1996), and this protein might be substituted by the related protein CAP-23 (Caroni, 1997), which could be induced in our experiments. Thus, the cell body reaction to axotomy involves the upregulation of a stereotyped gene set common to most nerve cells, including the examined cerebellar and precerebellar neurons.

It has been proposed that adult neurons respond to injury by suppressing genes involved in signal processing, typical of their mature phenotype, and upregulating growth-associated genes, characteristic of developmental processes (Hökfelt et al., 1994). However, despite the relationship existing between the expression of injury-induced genes and regenerative phenomena, to date their precise role in axon growth is still unclear, if not controversial, because many of them also have been related to cell death processes (Herdegen et al., 1997; Isenmann and Bähr, 1997). On the other hand, neuron degeneration and axon growth share, at least in part, common cellular pathways (Herdegen et al., 1997). Hence, pharmacological block of c-Jun kinase-1 in primary neurons prevents apoptosis but also inhibits axon growth (Markus et al., 1997). Overexpression of the $b c l-2$ gene prevents axotomy-induced degeneration (Bonfanti et al., 1996; Cenni et al., 1996) and enhances the regenerative capacity of retinal ganglion cells (Chen et al., 1997). Mouse Purkinje cells that overexpress GAP-43 show enhanced growth capabilities, together with a reduced resistance to axotomy-induced cell death (Buffo et al., 1997). These observations indicate that the cell body response to axon injury may result in very different outcomes ranging from

immunostaining $(f)$ shows the normal morphological features of Purkinje cells in such treated cerebella. A transected cerebellar lobule (dotted line points to the lesion track) that also received the Fab fragment injection is shown in g; arrowheads point to the numerous c-Jun-immunoreactive Purkinje cell nuclei, which also are located distantly from the lesion. Survival times: $2 \mathrm{~d}$ in $a-d, g ; 5 \mathrm{~d}$ in $e, f$. Scale bars: $20 \mu \mathrm{m}$ in $d, e ; 50 \mu \mathrm{m}$ in $b, c, f ; 100 \mu \mathrm{m}$ in $a, g$. 


\section{control Fab}

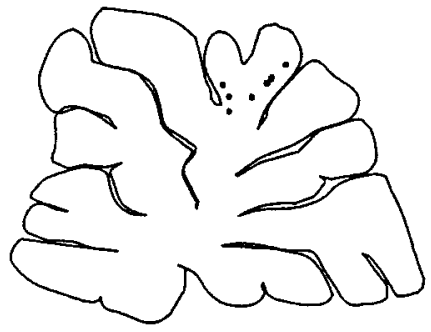

2d c-Jun

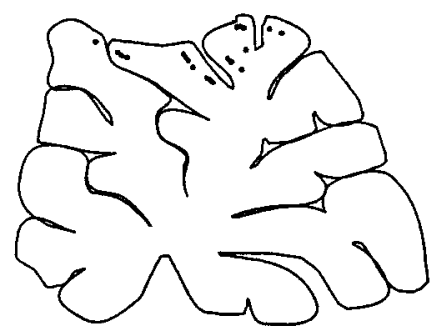

5d c-Jun

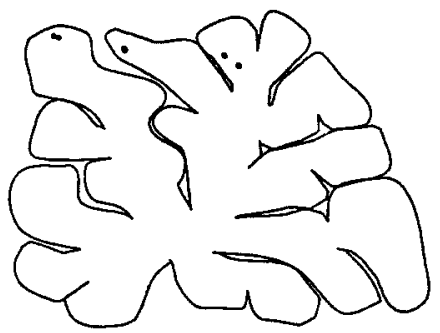

$5 d$ NADPHd

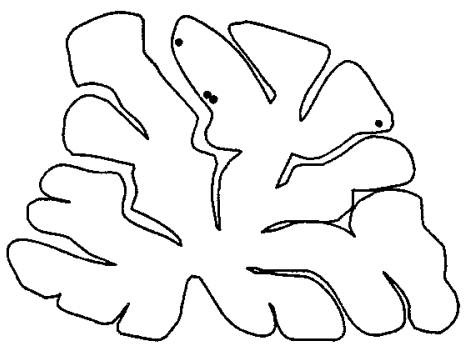

7d c-Jun

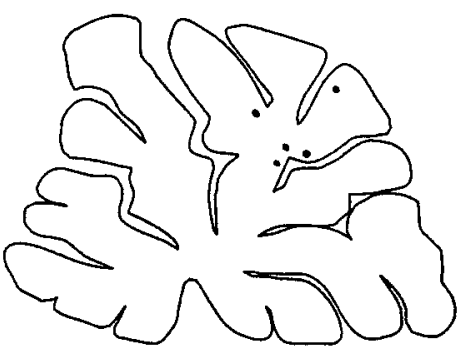

7d NADPHd
IN-1 Fab
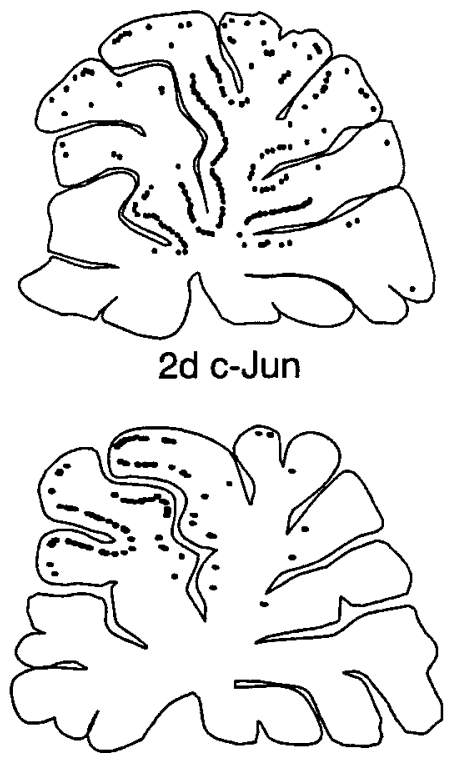

5d c-Jun

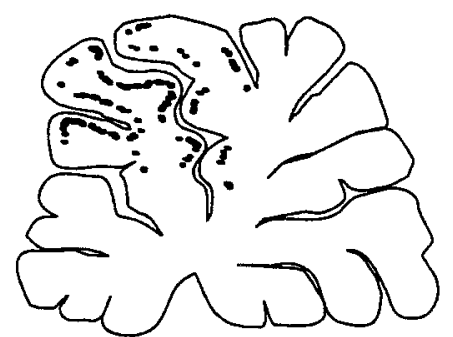

5d NADPHd

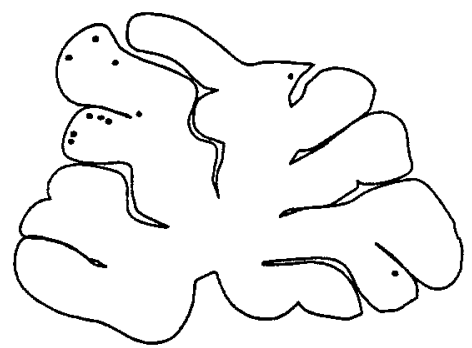

$7 d$ c-Jun

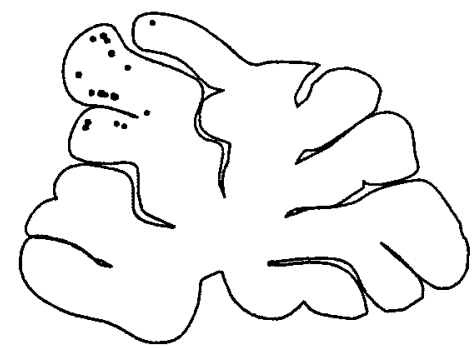

7d NADPHd
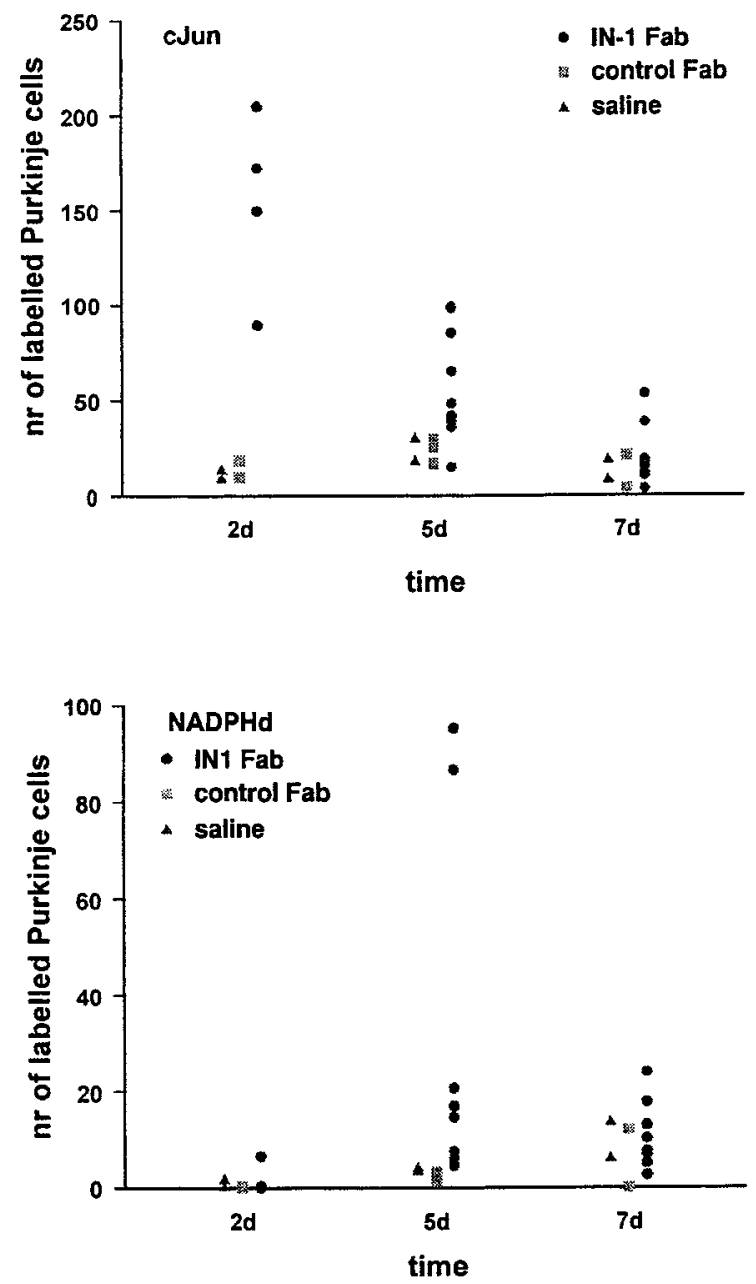

Figure 8. Spatial distribution and quantitative evaluation of c-Jun and NADPH diaphorase-positive Purkinje cells after the application of the Fab fragment of the IN-1 antibody or of the mouse-anti-human control Fab fragment. Neurolucida reconstructions of representative cerebellar sections labeled by c-Jun antibodies or NADPH diaphorase histochemistry at different survival times after injection are shown. After mouse-anti-human control Fab fragment injections (control Fab), only a few Purkinje cells (black dots) that are localized around the injection site become reactive for either marker. By contrast, numerous labeled Purkinje cells distributed over several cerebellar lobules are present in the IN-1 Fab (Figure legend continues) 
cell death to regeneration. However, it is clear that it is required to initiate axon growth; hence, the associated cellular changes can be taken as a reliable index of the regenerative potential of a neuron.

\section{Environmental control of growth-associated gene expression in adult neurons}

The constitutive capability for axon growth gradually declines as neurons mature (Skene, 1989, 1992); coincidentally, their regenerative potential is reduced also (Woodhams et al., 1993; Chen et al., 1995; Dusart et al., 1997). This phenomenon may be attributable either to intrinsic modifications associated with the acquisition of the adult neuronal phenotype (Bates and Meyer, 1997) or to the progressive appearance of growth inhibitory signals or the disappearance of growth-promoting factors (Kalil and Skene, 1986; Skene, 1989, 1992).

After axotomy, adult neurons often react by attempting to reexpress the growth-associated gene program. This response, however, may not be induced by injury per se but, rather, by the consequent removal of retrograde inhibitory signals. In the peripheral nervous system such signals are derived primarily from peripheral targets (Baizer and Fishman, 1987; Skene, 1989, 1992). Indeed, growth-associated genes can be upregulated in the absence of injury by target loss (Verzé et al., 1996) or block of the axon flow (Wu et al., 1993). Furthermore, the response to a distal axotomy is delayed but is not weaker than that induced by a proximal injury (Kenney and Kocsis, 1998), suggesting that influences acting along the axon do not contribute significantly to this regulation. In the $\mathrm{CNS}$, in contrast, complete target deprivation is not necessarily followed by a cell body reaction (Skene, 1989). However, the strength of this response depends on the distance between the injury and the cell body. The observation that retinal ganglion cells react equally well to an intraorbital optic nerve transection, irrespective of their distance from the optic disk, indicates that the crucial factor is not the actual distance of axon injury from the soma but, rather, the length of the remaining myelinated axon segment (Doster et al., 1991; Meyer et al., 1994). Thus, it has been proposed that growth-associated gene expression in the adult CNS is regulated by cues produced by nonneuronal elements present along mature white matter tracts (Skene, 1989, 1992; Doster et al., 1991; Meyer et al., 1994). The intimate nature of these cues has remained elusive up to date.

The behavior of adult Purkinje cells described here is fully consistent with these concepts: they react only to very proximal injuries, and a vigorous response can be elicited by blocking axonal flow. Interestingly, we found that injury-associated gene expression also can be induced by applying neutralizing antibodies against myelin-associated neurite growth inhibitory proteins in the absence of any lesion. The mechanism of action of the antibody as well as its actual ability to penetrate between myelin and axon to disrupt their interaction remains to be established. However, the specificity of this effect is supported by the observation that the neutralizing antibodies do not induce a similar response in granule cells or cortical interneurons in which the axons are unmyelinated (Palay and Chan-Palay, 1974). Thus, our results strongly support the conclusion that myelin-associated neurite growth inhibitory proteins are among the signaling molecules exerting a retrograde negative control on growthassociated gene expression in adult central neurons.

The discovery of NI-35 and NI-250 proteins has led to the notion that constitutive growth inhibitory mechanisms are active in the adult mammalian brain. The role of these proteins in preventing axon regeneration or sprouting after injury has been established in numerous experimental conditions (Schwab et al., 1993; Schwab and Bartholdi, 1996). As to their constitutive function in the intact brain, it has been proposed that the myelinassociated neurite growth inhibitory proteins could stabilize mature central fiber tracts and prevent adult axon sprouting, thus contributing to the maintenance of specific connections (Schwab et al., 1993; Colello and Schwab, 1994; Thallmair et al., 1998; Z'Graggen et al., 1998). This concept is supported by their time course of expression during development (Caroni and Schwab, 1989), their reciprocal distribution with GAP-43 (Kapfhammer and Schwab, 1994a,b), and the effects of their neutralization in developing uninjured white matter tracts (Schwab and Schnell, 1991). The present results provide evidence for a new additional function of these proteins: the active suppression of growthassociated gene expression. Thus, they may contribute to the developmental regulation of the axon growth program and, thereafter, may maintain adult neurons in the mature "nongrowing" condition by inhibiting growth cone motility and regulating gene expression.

After injury in the adult brain the amount of NI-35 and NI-250 protein remaining along the axon stump proximal to the lesion influences the strength of the reaction of the affected neurons. As a consequence, the specific regenerative capabilities of each neuron population do not depend solely on its intrinsic potential to express the growth-associated program but also on its degree of sensitivity to these environmental influences. Indeed, there are neuron populations with myelinated axons, such as inferior olivary neurons, that constitutively express growth-associated genes and are able to react and regenerate even after a distal axotomy. Thus, understanding the molecular mechanisms responsible for these interactions will be of major importance to improve substantially the reparative processes in the adult brain.

\section{REFERENCES}

Armengol JA, Sotelo C, Angaut P, Alvarado-Mallart RM (1989) Organization of host afferents to cerebellar grafts implanted into kainate lesioned cerebellum in adult rats. Hodological evidence for the specificity of host-graft interactions. Eur J Neurosci 1:75-93.

Baizer L, Fishman MC (1987) Recognition of specific targets by cultured dorsal root ganglion neurons. J Neurosci 7:2305-2311.

Bandtlow C, Schiweck W, Tai HH, Schwab ME, Skerra A (1996) The Escherichia coli-derived Fab fragment of the IgM/kappa antibody IN-1 recognizes and neutralizes myelin-associated inhibitors of neurite growth. Eur J Biochem 241:468-475.

Barron KD (1989) Neuronal responses to axotomy: consequences and possibilities for rescue from permanent atrophy or cell death. In: Neural regeneration and transplantation (Seil FJ, ed), pp 79-99. New York: Liss.

\footnotetext{
fragment-treated $(\mathrm{IN}-1 \mathrm{Fab})$ cerebella. Note the similar distribution of reactive neurons for either marker in the corresponding sections. The average number of labeled neurons per section is reported in the plots on the right side of the plate. Each point represents the value obtained from a single animal. A large number of c-Jun-labeled neurons (top plot) are present $2 \mathrm{~d}$ after injection. Their number gradually decreases thereafter and returns almost to basal levels at $7 \mathrm{~d}$. NADPH diaphorase-reactive Purkinje cells (bottom plot) are evident at $5 \mathrm{~d}$; two animals have $\sim 100$ cell per sections, whereas the others show a smaller number of labeled cells. Also, in this case the number of reactive neurons is close to control values at $7 \mathrm{~d}$. Note, however, that both the control Fab ( filled squares) or saline injections ( filled triangles) yielded only a small number of labeled cells per section, which was consistently lower than that counted in time-matched IN-1 Fab fragment-treated cerebella.
} 
Bates CA, Meyer RL (1997) The neurite-promoting effect of laminin is mediated by different mechanisms in embryonic and adult regenerating mouse optic axons. Dev Biol 181:91-101.

Bonfanti L, Strettoi E, Chierzi S, Cenni MC, Liu X-H, Martinou J-C, Maffei L, Rabacchi S (1996) Protection of retinal ganglion cells from natural and axotomy-induced cell death in neonatal transgenic mice overexpressing $b c l$-2. J Neurosci 16:4186-4194.

Bravin M, Savio T, Strata P, Rossi F (1997) Olivocerebellar axon regeneration and target reinnervation following dissociated Schwann cell grafts in surgically injured cerebella of adult rats. Eur J Neurosci 9:2634-2649.

Broude E, McAtee M, Kelley MS, Bregman BS (1997) c-Jun expression in adult dorsal root ganglion neurons: differential response after central or peripheral axotomy. Exp Neurol 148:367-377.

Buffo A, Holtmaat AJ, Savio T, Verbeek JS, Oberdick J, Oestreicher AB, Gispen WH, Verhaagen J, Rossi F, Strata P (1997) Targeted overexpression of the neurite growth-associated protein B-50/GAP-43 in cerebellar Purkinje cells induces sprouting in response to axotomy, but does not allow axon regeneration into growth permissive transplants. J Neurosci 17:8778-8791.

Buffo A, Fronte M, Oestreicher AB, Rossi F (1998) Degenerative phenomena and reactive modifications of the adult rat inferior olivary neurons following axotomy and disconnection from their targets. Neuroscience 85:587-604.

Caroni P (1997) Intrinsic neuronal determinants that promote axonal sprouting and elongation. BioEssays 19:767-775.

Caroni P, Schwab ME (1988a) Two membrane protein fractions from rat central myelin with inhibitory properties for neurite growth and fibroblast spreading. J Cell Biol 106:1281-1288.

Caroni P, Schwab ME (1988b) Antibody against myelin-associated inhibitor of neurite growth neutralises nonpermissive substrate properties of CNS white matter. Neuron 1:85-96.

Caroni P, Schwab ME (1989) Codistribution of neurite growth inhibitors and oligodendrocytes in rat CNS: appearance follows nerve fiber growth and precedes myelination. Dev Biol 136:287-295.

Cenni MC, Bonfanti L, Martinou J-C, Ratto GM, Strettoi E, Maffei L (1996) Long-term survival of retinal ganglion cells following optic nerve section in adult $b c l-2$ transgenic mice. Eur $\mathrm{J}$ Neurosci 8:1735-1745.

Chen DF, Jhavery S, Schneider GE (1995) Intrinsic changes in developing retinal neurons results in regenerative failure of their axons. Proc Natl Acad Sci USA 92:7287-7291.

Chen DF, Schneider GE, Martinou J-C, Tonegawa S (1997) bcl-2 promotes regeneration of severed axons in mammalian CNS. Nature 385:434-439.

Chen S, Aston-Jones G (1994) Cerebellar injury induces NADPH diaphorase in Purkinje and inferior olivary neurons in the rat. Exp Neurol 126:270-276.

Chong MS, Reynolds ML, Irwin N, Coggeshall RE, Emson PC, Benowitz LI, Woolf CJ (1991) GAP-43 expression in primary sensory neurons following central axotomy. J Neurosci 11:4375-4384.

Chong MS, Woolf CJ, Turmaine M, Emson PC, Anderson PN (1996) Intrinsic versus extrinsic factors in determining the regeneration of the central processes of rat dorsal root ganglion neurons: the influence of a peripheral nerve graft. J Comp Neurol 370:97-104.

Colello RJ, Schwab ME (1994) A role for oligodendrocytes in the stabilization of optic axon numbers. J Neurosci 14:6446-6452.

Console-Bram LM, Fitzpatrick-McElligott SG, McElligott JG (1996) Distribution of GAP-43 mRNA in the immature and adult cerebellum: a role for GAP-43 in cerebellar development and neuroplasticity. Dev Brain Res 95:97-106.

Dasheff RM, Ramirez LF (1985) The effects of colchicine in mammalian brain from rodents to rhesus monkey. Brain Res Rev 10:47-67.

Dooley JM, Aguayo AJ (1982) Axonal elongation from cerebellum into peripheral nervous system grafts in the adult rat. Ann Neurol 12:221.

Doster KS, Lozano AM, Aguayo AJ, Willard MB (1991) Expression of the growth-associated protein GAP-43 in adult rat retinal ganglion cells following injury. Neuron 6:635-647.

Dusart I, Sotelo C (1994) Lack of Purkinje cell loss in adult rat cerebellum following protracted axotomy: degenerative changes and regenerative attempts of severed axons. J Comp Neurol 347:211-232.

Dusart I, Airaksinen MS, Sotelo C (1997) Purkinje cell survival and regeneration are age-dependent: an in vitro study. J Neurosci 17:3710-3726.
Fawcett JW (1992) Intrinsic neuronal determinants of regeneration. Trends Neurosci 15:5-8.

Gold BG, Storm-Dickerson T, Austin DR (1993) Regulation of the transcription factor c-Jun by nerve growth factor in adult sensory neurons. Neurosci Lett 154:129-133.

Goldschmidt RB, Steward O (1982) Neurotoxic effects of colchicine: differential susceptibility of CNS neuronal populations. Neuroscience 7:695-714.

Herdegen T, Zimmermann M (1994) Expression of c-Jun and JunD transcription factors represent specific changes in neuronal gene expression following axotomy. In: Neural regeneration. Progress in brain research, Vol 103 (Seil FJ, ed), pp 153-171. Amsterdam: Elsevier.

Herdegen T, Brecht S, Mayer B, Leah J, Kummer W, Bravo R, Zimmermann M (1993) Long-lasting expression of JUN and KROX transcription factors and nitric oxide synthase in intrinsic neurons of the brain following axotomy. J Neurosci 13:4130-4145.

Herdegen T, Kovary K, Buhl A, Bravo R, Zimmermann M, Gass P (1995) Basal expression of the inducible transcription factors c-Jun, JunB, JunD, c-Fos, FosB, and Krox-24 in the adult rat brain. J Comp Neurol 354:39-56.

Herdegen T, Skene JHP, Bähr M (1997) The c-Jun transcription factor-bipotential mediator of neuronal death, survival, and regeneration. Trends Neurosci 20:227-231.

Hökfelt T, Zhang X, Wiesenfeld-Hallin Z (1994) Messenger plasticity in primary sensory neurons following axotomy and its functional implications. Trends Neurosci 17:22-30.

Hüll M, Bähr M (1994a) Differential regulation of c-Jun expression in rat retinal ganglion cells after proximal and distal optic nerve transection. Neurosci Lett 178:39-42.

Hüll M, Bähr M (1994b) Regulation of immediate early gene expression in retinal ganglion cells following axotomy and during regeneration through a peripheral nerve graft. J Neurobiol 25:92-105.

Isenmann S, Bähr M (1997) Expression of c-Jun protein in degenerating retinal ganglion cells after optic nerve lesion in the rat. Exp Neurol 147:28-36.

Jenkins R, McMahon SB, Bond AB, Hunt SP (1993) Expression of c-Jun as a response to dorsal root and peripheral nerve section in damaged and adjacent intact primary sensory neurons in the rat. Eur J Neurosci 5:751-759.

Kalil K, Skene JHP (1986) Elevated synthesis of an axonally transported protein correlates with axon outgrowth in normal and injured pyramidal tracts. J Neurosci 6:2563-2570.

Kapfhammer JP, Schwab ME (1994a) Inverse patterns of myelination and GAP-43 expression in the adult CNS: neurite growth inhibitors as regulators of neuronal plasticity? J Comp Neurol 340:194-206.

Kapfhammer JP, Schwab ME (1994b) Increased expression of the growth-associated protein GAP-43 in myelin-free rat spinal cord. Eur J Neurosci 6:403-411.

Kapfhammer JP, Christ F, Schwab ME (1997) The growth-associated protein GAP-43 is specifically expressed in tyrosine hydroxilasepositive cells of the rat retina. Dev Brain Res 101:257-264.

Kenney AM, Kocsis JD (1998) Peripheral axotomy induces long-term c-Jun N-terminal kinase-1 activation and activator protein-1 binding activity by c-Jun and JunD in adult dorsal root ganglia in vivo. J Neurosci 18:1318-1328.

Kobayashi NR, Fan D-P, Giehl KM, Bedard AM, Wiegand SJ, Tetzlaff W (1997) BDNF and NT4/5 prevent atrophy of rat rubrospinal neurons after cervical axotomy, stimulate GAP-43 and T $\alpha 1$-tubulin mRNA expression, and promote axonal regeneration. J Neurosci 17:9583-9595.

Kruger L, Bendotti C, Rivolta R, Samanin R (1993) Distribution of GAP-43 mRNA in the adult rat brain. J Comp Neurol 333:417-434.

Leah J, Herdegen T, Murashov A, Dragunow M, Bravo R (1993) Expression of immediate early gene proteins following axotomy and inhibition of axonal transport in the rat central nervous system. Neuroscience 57:53-66.

Lieberman AR (1971) The axon reaction: a review of the principal features of perikaryal response to axon injury. Int Rev Neurobiol 24:49-124.

Markus MA, Kahle P, Winkler A, Horstmann S, Anneser JMH, Borasio GD (1997) Survival-promoting activity of inhibitors of cyclindependent kinases on primary neurons correlates with inhibition of c-Jun kinase-1. Neurobiol Dis 3:122-133.

Meyer RL, Miotke JA, Benowitz LI (1994) Injury-induced expression of growth-associated protein-43 in adult mouse retinal ganglion cells in vitro. Neuroscience 63:591-602. 
Munz M, Rasminsky M, Aguayo AJ, Vidal-Sanz M, Devor MG (1985) Functional activity of rat brainstem neurons regenerating axons along peripheral nerve grafts. Brain Res 340:115-125.

Palay SL, Chan-Palay V (1974) Cerebellar cortex. Cytology and organization. Berlin: Springer.

Pioro EP, Cuello AC (1988) Purkinje cells of adult rat cerebellum express nerve growth factor receptor immunoreactivity: light microscopic observations. Brain Res 455:182-186.

Robinson GA (1995) Axotomy-induced regulation of c-Jun expression in regenerating rat retinal ganglion cells. Mol Brain Res 30:61-69.

Rossi F, Jankovski A, Sotelo C (1995) Differential regenerative response of Purkinje cell and inferior olivary axons confronted with embryonic grafts: environmental cues versus intrinsic neuronal determinants. J Comp Neurol 359:663-677.

Saxon DW, Beitz AJ (1994) Cerebellar injury induces NOS in Purkinje cells and cerebellar afferents. NeuroReport 5:809-812.

Saxon DW, Beitz AJ (1996) Induction of NADPH-diaphorase/nitric oxide synthase in the brainstem trigeminal system resulting from cerebellar lesions. J Comp Neurol 371:41-71.

Schaden H, Stürmer CAO, Bähr M (1994) GAP-43 immunoreactivity and axon regeneration in retinal ganglion cells of the rat. J Neurobiol 25:1570-1578.

Schwab ME, Bartholdi D (1996) Degeneration and regeneration of axons in the lesioned spinal cord. Physiol Rev 76:319-370.

Schwab ME, Schnell L (1991) Channeling of developing rat corticospinal axons by myelin-associated neurite growth inhibitors. J Neurosci 11:709-722.

Schwab ME, Kapf hammer JP, Bandtlow CE (1993) Inhibitors of neurite growth. Annu Rev Neurosci 16:565-595.

Skene JHP (1989) Axonal growth-associated proteins. Annu Rev Neurosci 12:127-156.

Skene JHP (1992) Retrograde pathways controlling expression of a major growth cone component in the adult CNS. In: The nerve growth cone (Letourneau PC, Kater SB, Macagno ER, eds), pp 463-475. New York: Raven.
Smith DS, Skene JHP (1997) A transcription-dependent switch controls competence of adult neurons for distinct modes of axon growth. J Neurosci 17:646-658.

Tetzlaff W, Kobayashi NR, Giehl KMG, Tsui BJ, Cassar SL, Bedard AM (1994) Response of rubrospinal and corticospinal neurons to injury and neurotrophins. In: Neural regeneration. Progress in brain research, Vol 103 (Seil FJ, ed), pp 271-286. Amsterdam: Elsevier.

Thallmair M, Metz GAS, Z'Graggen WJ, Raineteau O, Kartje GL, Schwab ME (1998) Structural plasticity parallels functional recovery following adult CNS lesion and treatment with antibodies to neurite growth inhibitors. Nat Neurosci 1:124-131.

Vaudano E, Campbell G, Anderson PN, Davies AP, Woolhead C, Schreyer DJ, Lieberman AR (1995) The effects of a lesion or a peripheral nerve graft on GAP-43 upregulation in the adult brain: an in situ hybridization and immunocytochemical study. J Neurosci 15:3594-3611.

Verzè L, Buffo A, Rossi F, Oestreicher AB, Gispen WH, Strata P (1996) Increase of B-50/GAP-43 immunoreactivity in uninjured muscle nerves of $m d x$ mice. Neuroscience 70:807-815.

Voogd J, Gerrits N, Marani E (1985) Cerebellum. In: The rat nervous system, Vol 2 (Paxinos G, ed), pp 251-292. New York: Academic.

Woodhams PL, Atkinson DJ, Raisman G (1993) Rapid decline in the ability of entorhinal axon to innervate the dentate gyrus with increasing time in organotypic coculture. Eur J Neurosci 5:1596-1609.

Wu W, Mathew TC, Miller FD (1993) Evidence that the loss of homeostatic signals induces regeneration-associated alterations in neuronal gene expression. Dev Biol 158:456-466.

Yang DD, Kuan C-Y, Whitmarsh AJ, Rincón M, Zheng TS, Davis RJ, Rakic P, Flavell RA (1997) Absence of excitotoxicity-induced apoptosis in the hippocampus of mice lacking the Jnk3 gene. Nature 389:865-870.

Z'Graggen WJ, Metz GAS, Kartje GL, Thallmair M, Schwab ME (1998) Functional recovery and enhanced cortico-fugal plasticity after unilateral pyramidal tract lesion and blockade of myelin-associated neurite growth inhibitors in adult rats. J Neurosci 18:4744-4757. 